\title{
AVALIAÇÃo DE METOdOLOGIA PARA ESTUdO DA AÇÃO DE ALGUNS ANTIMICROBIANOS FRENTE A BACTÉRIAS GRAM (+) ISOLADAS DA FERMENTAÇÃO ALCOÓLICA
}

\author{
MARIA DA GRAÇA STUPIELLO \\ Bióloga
}

Orientador: ANTONIO JOAQUIM DE OLIVEIRA

Dissertação apresentada à Escola Superior de Agricultura "Luiz de Queiroz", da Universidade de São Paulo, para obtenção do título de Mestre em Ciência. Área de concentração: Ciência e Tecnologia de Alimentos

\author{
Piracicaba \\ Estado de são Paulo - Brasil \\ Agosto de 1993
}


Ficha catalografica preparada pela Seçào de Livros da Divisáo de Bibliateca e Documentaçăo - FCLQ/USF

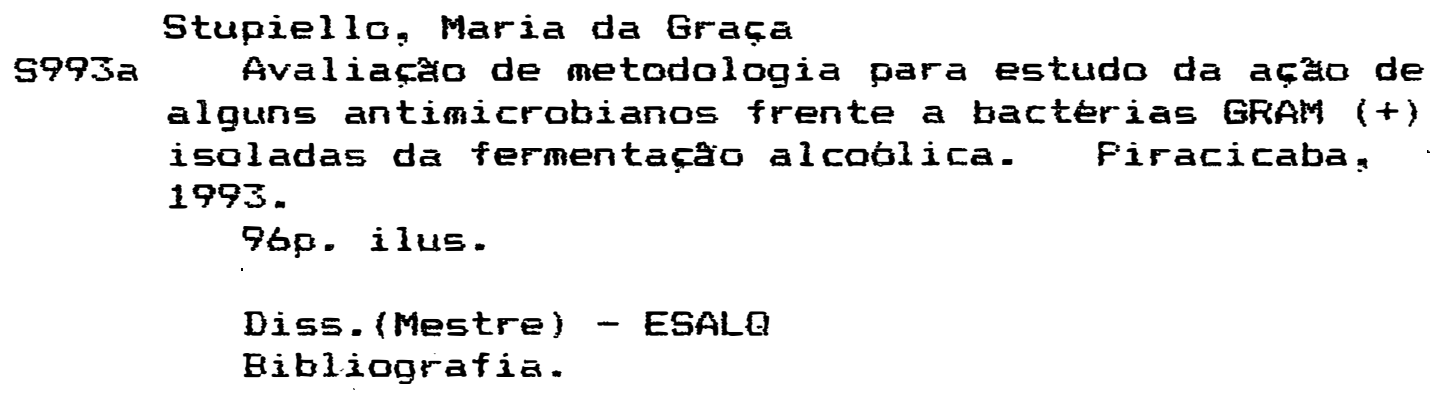

1. Antimicrobiano 2. Eacteria 3. Fermentạ̧ăo alcotica I. Escela Superior de Agricultura Luiz de Queiroz, Firacicaba 


\section{AVALIAÇÃO DE METOdOLOGIA PARA ESTUdO DA AÇÃO DE ALGUNS ANTIMICROBIANOS FRENTE A BACTÉRIAS GRAM (+) ISOLADAS DA FERMENTAÇÃO ALCOÓLICA}

MARIA DA GRAÇA STUPIELLO

Aprovada em: 17.09 .93

Comissão julgadora:

Prof. Dr. Claudio Rosa Gallo BSALQ/USP

Prof $^{a}$. Dr ${ }^{a}$. Djanira de Franceschi de Angelis UNBSP/R. CLARO

Prof. Dr. Antoniq Juatuim $\approx$ oliveira

Orientador 
Dedico à D. Aurora, que me ensinou a ser forte para enfrentar a vida 
Ofereço às pessoas mais importantes da minha vida: Jaime, Jorgette, José Paulo e Silvio 


\section{AGRADBCIMENTOS}

Agradecemos aqueles que de por alguma forma contribuiram para a realização deste trabalho e em especial:

Ao professor Antonio Joaquim de Oliveira pela orientação e confiança depositada.

A Fundação de Amparo a Pesquisa do Estado de São Paulo pelo auxílio financeiro para este trabalho.

Ao Conselho Nacional de Desenvolvimento Cientifico e Tecnológico pelo auxílio concedido na forma de bolsa de estudo.

Ao Departamento de Tecnologia AgroIndustrial assim como aos professores deste departamento pela oportunidade concebida para a realização deste trabalho.

A professora Isabel Ito da Faculdade de Farmácia de Ribeirão Preto (USP) pelo exemplo de dedicação para com os que iniciam na pesquisa.

A Usina Ester na pessoa de F. Zarpelon pela confecção de parte do material utilizado neste trabalho.

A Fundação Tropical de Pesquisas "André Tosselo" pela doação das culturas.

Em especial ao Sílvio, pela dedicação demonstrada, não só nesta, mas em todas as etapas da minha vida.

Aos amigos : Cleomar, Walmir, Adriana, Verinha, Teresinha, Regina, Nélia, Bel, Chico, Adriana Galvão que de alguma forma muito especial participaram da realização deste trabalho. 


\section{SUMARIO}

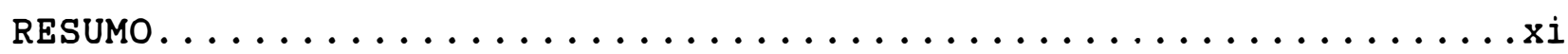

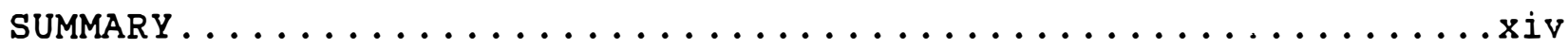

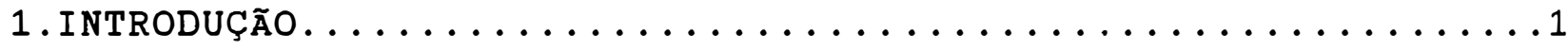

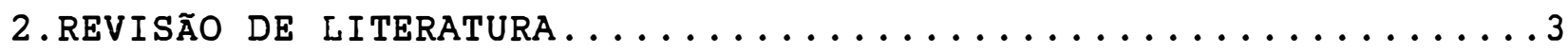

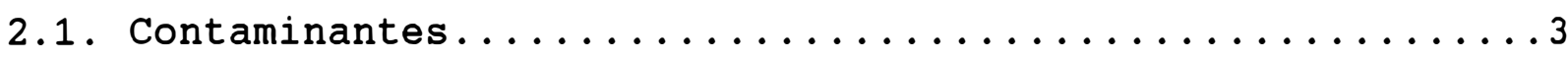

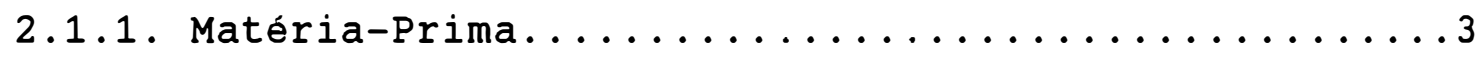

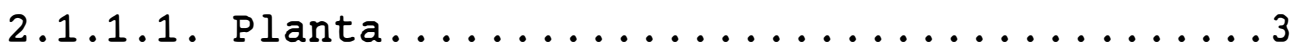

2.1.2. Práticas Agrícolas....................

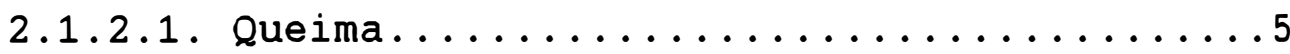

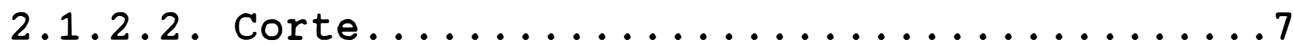

2.1.3. Industrialização...................

2.1.3.1. Armazenamento..................

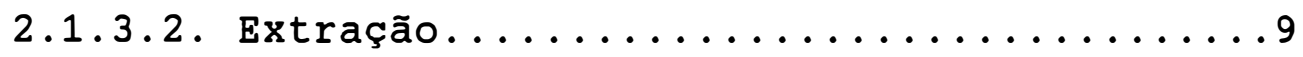

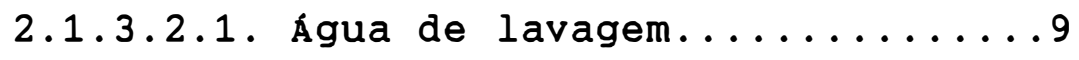

2.1.3.2.2. Equipamentos...........10

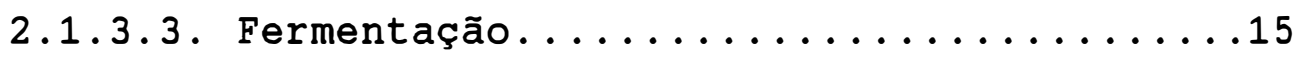

2.2. Consequências dos contaminantes no processo

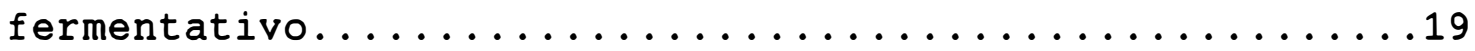

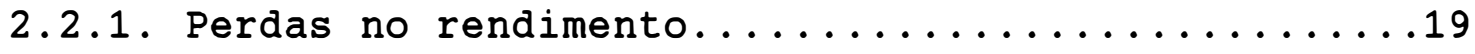

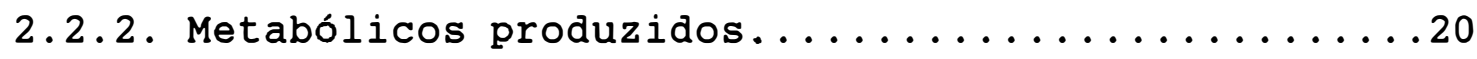

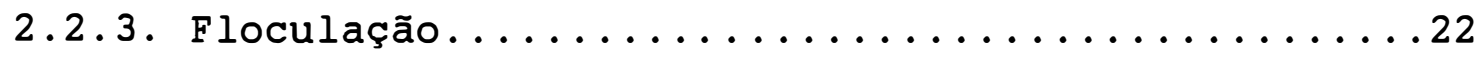

2.3. Antimicrobianos na fermentação..................24

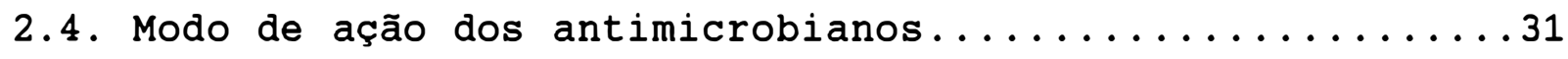




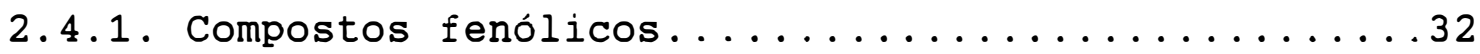

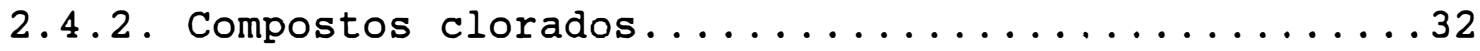

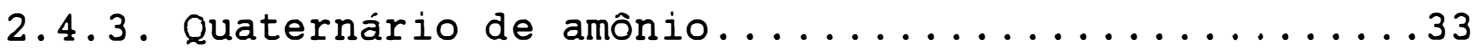

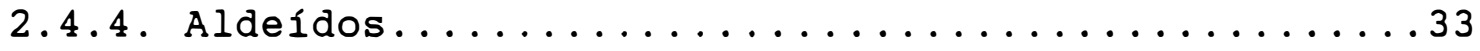

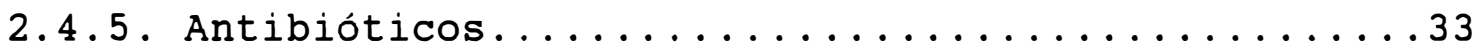

2.5. Metodologia para avaliação de antimicrobiano.........34

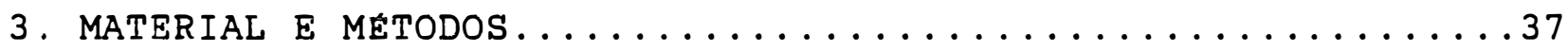

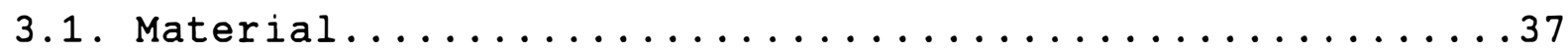

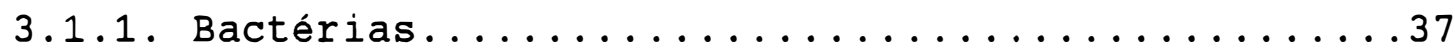

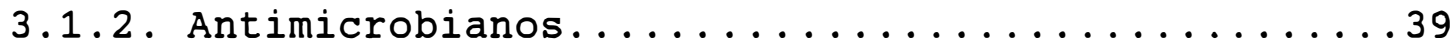

3.1.3. Meio de cultivo...................40

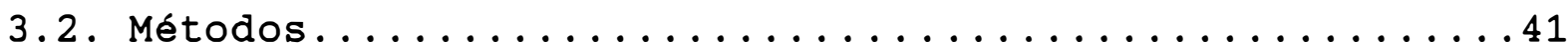

3.2.1. Manutenção das bactérias...............41

3.2.2. Preparo dos antimicrobianos..............41

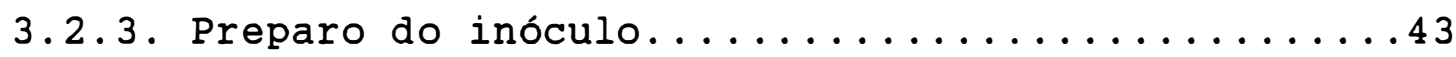

3.2.4. Concentração Inibitória Mínima (C.I.M)........43

3.2.4.1. Concentração Inibitória Mínima em meio sólido (C.I.M.S)...........43

3.2.4.1.1. Preparo das placas.......43

3.2.4.1.2. Inoculação............44

3.2.4.1.3. Leitura.............45

3.2.4.2. Concentração Inibitória Mínima em meio líquido (C.I.M.L)..........45

3.2.4.2.1. Preparo dos tubos........45

3.2.4.2.2. Inoculacão..........45

3.2.4.2.3. Leitura.............45 
3.2.5. Concentração Bactericida Mínima (C.B.M).......46 3.2.5.1. Preparo dos tubos.............46 3.2 .5 .2 . Inoculação................46

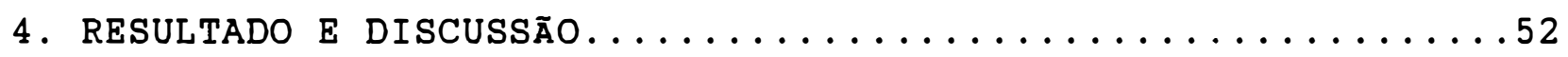

4.1. Metodologia para avaliação de C.I.M..............52

4.2. Ação dos antimicrobianos sobre as bactérias.........56 4.2.1. Lactobacillus buchneri..............56

4.2.2. Lactobacillus fermentum................59

4.2.3. Lactobacillus plantarum...............62

4.2.4. Leuconostoc mesenteroides..............64

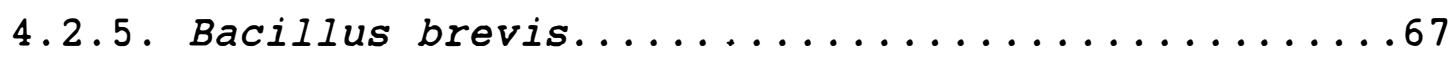

4.2.6. Bacillus megaterium................69

4.2.7. Bacillus coagulans..................71

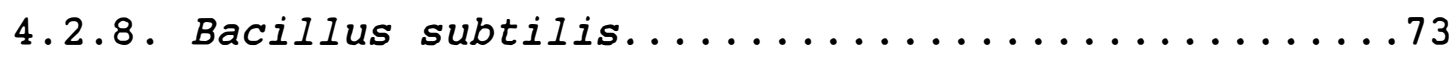

4.3. Escolha do microrganismo teste..............76

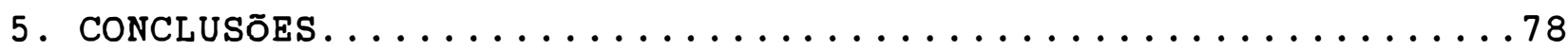

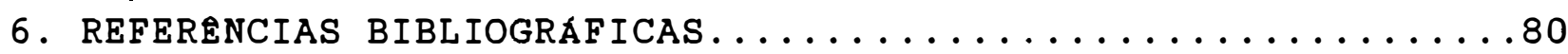




\section{LISTA DE TABELAS}

\section{TABELA №}

Página

01 Doses utilizadas para cada um dos antimicrobianos testados................40 Concentração Inibitória Mínima (C.I.M) em meio líquido (C.I.M.L) e sólido (C.I.M.S) e Concentração Bactericida Mínima (C.B.M) para todas as bactérias estudadas frente aos antimicrobianos: CL - Cloranfenicol, FM - Fermacol, PC - Penicilina, Q.A - Quaternário de amônio e VM - Vir-

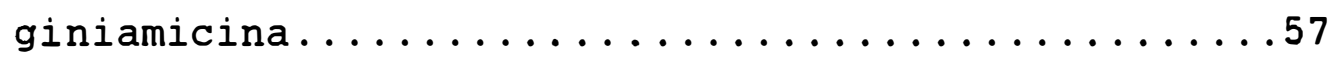




\section{LISTA DE FIGURAS}

FIGURA NO

01

02

03

04

05

06

07

08

09

10
Manutenção das bactérias.................42

Preparo do antimicrobiano.................42

Aplicador preconizado por STERRS et alii (1959)..48

Crescimento das bactérias da placa controle (18

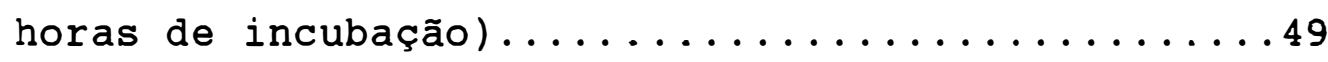

Concentração Inibitória Mínima em meio sólido....50

Concentração Inibitória Mínima em meio líquido...51

Concentração Bactericida Mínima...............51

Ação dos antimicrobianos testados sobre $L$.

buchneri quanto à: C.I.M.L, C.I.M.S e C.B.M

onde CL - Cloranfenicol, FM - Fermacol, PC -

Penicilina, Q.A - Quaternário de amônio e VM

- Virginiamicina e N.D. - não detectado........58

Ação dos antimicrobianos testados sobre $L$.

fermentum quanto à: C.I.M.L, C.I.M.S e C.B.M onde CL - Cloranfenicol, FM - Fermacol, PC Penicilina, Q.A - Quaternário de amônio e VM

- Virginiamicina e N.D. - não detectado........61

Ação dos antimicrobianos testados sobre $L$.

plantarum quanto à: C.I.M.L, C.I.M.S e C.B.M onde CL - Cloranfenicol, FM - Fermacol, PC Penicilina, Q.A - Quaternário de amônio e VM - Virginiamicina e N.D. - não detectado.........63 
Ação dos antimicrobianos testados sobre $L$. mesenteroides quanto à: C.I.M.L, C.I.M.S e C.B.M onde CL - Cloranfenicol, FM - Fermacol, PC Penicilina, Q.A - Quaternário de amônio e VM - Virginiamicina e N.D. - não detectado........66 Ação dos antimicrobianos testados sobre $B$. brevis quanto à: C.I.M.I, C.I.M.S e C.B.M onde CL - Cloranfenicol, FM - Fermacol, PC Penicilina, Q.A - Quaternário de amônio e VM - Virginiamicina e N.D. - não detectado........68 Ação dos antimicrobianos testados sobre $B$. megaterium quanto à: C.I.M.L, C.I.M.S e C.B.M onde CL - Cloranfenicol, FM - Fermacol, PC Penicilina, Q.A - Quaternário de amônio e VM - Virginiamicina e N.D. - não detectado.........70 14 Ação dos antimicrobianos testados sobre $B$. coagulans quanto à: C.I.M.L, C.I.M.S e C.B.M onde CL - Cloranfenicol, FM - Fermacol, PC Penicilina, Q.A - Quaternário de amônio e VM - Virginiamicina e N.D. - não detectado.........72 15 Ação dos antimicrobianos testados sobre $B$. subtilis quanto à: C.I.M.L, C.I.M.S e C.B.M onde CL - Cloranfenicol, FM - Fermacol, PC Penicilina, Q.A - Quaternário de amônio e VM - Virginiamicina e N.D. - não detectado.........75 


\title{
AVALIAÇÃO DE METODOLOGIA PARA ESTUDO DA AÇ̃̃O DE ALGUNS ANTIMICROBIANOS FRENTE A BACTERIAS GRAM (+) ISOLADAS DA FERMENTAÇÃO ALCOOLLICA
}

\author{
Candidata: MARIA DA GRAÇA STUPIELLO \\ Orientador: ANTONIO JOAQUIM DE OLIVEIRA
}

\section{RESUMO}

Dois diferentes parâmetros foram testados para obtenção da Concentração Inibitória Mínima (C.I.M) em bactérias $\operatorname{Gram}^{(+)}$ isoladas da fermentação alcoólica sendo um em meio líquido (C.I.M.L) e outro em meio sólido (C.I.M.S). Quando se comparou os dois parâmetros testados apenas seis (6) dos quarenta (40) testes realizados diferiram nos valores obtidos, sendo que em todos estes valores, os maiores foram obtidos para C.I.M.S. O trabalho ainda procurou determinar Concentração Bactericida Mínima (C.B.M) para as bactérias testadas, sendo que das quarenta (40) combinações bactérias/antimicrobianos testados apenas em dezoito (18) delas esses resultados foram obtidos.

Os antimicrobianos testados foram cloranfenicol, fermacol, penicilina, quaternário de amônio e virginiamicina nas concentrações normalmente recomendadas para as unidades industriais e quatro (4) doses acima e duas (2) abaixo, em associação com as seguintes bactérias: Lactobacillus buchneri, L. fermentum, L. plantarum, Leuconostoc 
mesenteroides, Bacillus brevis, B. megaterium, B. coagulans

e B. subtilis.

Os valores de C.I.M.S obtidos para os antimicrobianos cloranfenicol, fermacol, penicilina, quaternário de amônio e virginiamicina sobre os microrganismos foram respectivamente (ppm) :

- L. buchneri : 8; 2; 0,5; 10 e 0,25;

- L. fermentum : não detectado; 2; 0,5; 10 e 0,25;

- L. plantarum : não detectado; não detectado; não detectado; 10 e não detectado;

- L. mesenteroides : não detectado; 2; 0,5; 10 e 0,25;

- B. brevis : não detectado; 2; 0,5; 10 e 0,25;

- B. megaterium: 4; 0,25; 0,5; 10 e 0,25;

- B. coagulans : 4; 0,25; não detectado; 10 e 0,5; e

- B. subtilis: $4 ; 0,25 ; 2 ; 10$ e 1 .

Os valores de C.I.M.L obtidos para os antimicrobianos cloranfenicol, fermacol, penicilina, quaternário de amônio e virginiamicina sobre os microrganismos foram respectivamente $(\mathrm{ppm}):$

- L. buchneri : 8; 1; 0,5; 10 e 0,25;

- L. fermentum : não detectado; $1 ; 0,5 ; 10$ e 0,25;

- L. plantarum : não detectado; não detectado; não detectado; 10 e não detectado;

- L. mesenteroides : não detectado; $1 ; 0,5 ; 10$ e 0,25;

- B. brevis : não detectado; 1; 0,5; 10 e 0,25;

- B. megaterium : $4 ; 0,25 ; 0,5 ; 10$ e 0,25 ; 
- B. coagulans : 4; 0,25; não detectado; 10 e 0,5; e

- B. subtilis : $2 ; 0,25 ; 2 ; 10$ e 0,5 .

Os valores de C.B.M obtidos para os antimicrobianos cloranfenicol, fermacol, penicilina, quaternário de amônio e virginiamicina sobre os microrganismos foram respectivamente $(\mathrm{ppm})$ :

- L. buchneri : não detectado; não detectado; 8; 40 e 0,5;

- L. fermentum : não detectado; não detectado; não detectado; 40 e não detectado;

- L. plantarum : não detectado; não detectado; não detectado; 80 e não detectado;

- L. mesenteroides : não detectado; não detectado; não detectado; 80 e não detectado;

- B. brevis : não detectado; não detectado; 8; 40 e 16;

- B. megaterium : não detectado; 4; não detectado; 40 e 2;

- B. coagulans : não detectado; 4; não detectado; 40 e 2; e

- B. subtilis : não detectado; 2; não detectado; 40 e 2 .

* Não detectado significa que o valor do parâmetro não foi obtido na maior concentração testada para o referido antimicrobiano. 
AVALIATION OF STUDY METHODOLOGY OF SOME ANTIMICROBIAL PRODUCTS ACTION UPON GRAM (+) BACTERIAS ISOLATED FROM ALCOHOL FERMENTATION

Candidate: MARIA DA GRAÇA STUPIELLO Adviser: ANTONIO JOAQUIM DE OLIVEIRA

\section{SUMMARY}

Two differents parameters were carried out to obtain minimal inhibitory concentration (M.I.C) in bacterias Gram + isolated from alcohol fermentation, one in broth medium (M.I.C.B) and the other in agar (M.I.C.A).

When comparing the two methodologies only six (6) of the forty (40) tests done differed in the obtained values, considering that in all theses tests higher values were obtained to M.I.C.A. Effort were made in order to determine minimal bactericidal concentration (M.B.C) for the studied bacteria, taking into account that of the forty (40) bacteria/antimicrobial combinations only eighteen (18) presented theses results.

The antimicrobial tested were choramphenicol, "fermacol", penicillin, quartenary ammonium and virginiamycin in the concentrations usually recommended for industrial units and four (4) doses higher and two (2) lower, associated to the following bacterias: Lactobacillus buchneri, $L$. fermentum, L. plantarum, Leuconostoc mesenteroides, Bacillus 
brevis, B. megaterium, B. coagulans and B. subtilis.

The results of M.I.C.A obtaind for the antimicrobial products choramphenicol, "fermacol", penicillin, quartenary ammonium and virginiamycin upon the microorganism respectively were $(\mathrm{ppm})$ :

- L. buchneri : 8; 2; $0.5 ; 10$ and $0.25 ;$

- L. fermentum : non detected; $2 ; 0.5 ; 10$ and 0.25 ;

- L. plantarum : non detected; non detected; non detected; 10 and non detected;

- L. mesenteroides : non detected; $2 ; 0.5 ; 10$ and 0.25 ;

- B. brevis : non detected; $2 ; 0.5 ; 10$ and 0.25 ;

- B. megaterium : 4;0.25; 0.5; 10 and $0.25 ;$

- B. coagulans : 4; $0.25 ;$ non detected; 10 and $0.5 ;$ and

- B. subtilis : 4; $0.25 ; 2 ; 10$ and 1 .

The results of M.I.C.B obtaind for the antimicrobial products choramphenicol, "fermacol", penicillin, quartenary ammonium and virginiamycin upon the microorganism respectively were $(\mathrm{ppm})$ :

- L. buchneri : 8; 1; 0.5; 10 and 0.25;

- L. fermentum : non detected; $1 ; 0.5 ; 10$ e 0.25;

- L. plantarum : non detected; non detected; non detected; 10 and non detected;

- L. mesenteroides : non detected; $1 ; 0.5 ; 10$ and 0.25 ;

- B. brevis : non detected; $1 ; 0.5 ; 10$ and 0.25 ;

- B. megaterium : 4; $0.25 ; 0.5 ; 10$ and 0.25 ;

- B. coagulans : 4; 0.25; non detected; 10 and 0.5; and 
- B. subtilis : $2 ; 0.25 ; 2 ; 10$ and 0.5 .

The results of M.B.C obtaind for the antimicrobial products choramphenicol, "fermacol", penicillin, quartenary ammonium and virginiamycin upon the microorganism respectively were $(\mathrm{ppm})$ :

- L. buchneri : non detected; non detected; 8; 40 and 0.5;

- L. fermentum : non detected; non detected; non detected; 40 and non detected;

- L. plantarum : non detected; non detected; non detected; 80 and non detected;

- L. mesenteroides : non detected; non detected; non detected; 80 and non detected;

- B. brevis : non detected; non detected; 8; 40 and 16;

- B. megaterium : non detected; 4; non detected; 40 and 2;

- B. coagulans : non detected; 4; non detected; 40 and 2; and

- B. subtilis : non detected; 2; non detected; 40 and 2 .

* Non detected means that the parameter value was not obtained to higher concentration used to each antimicrobial. 


\section{INTRODUÇÃO}

Com a implantação do Proálcool - Programa Nacional de Álcool em 1975, o Brasil tornou-se o primeiro país do mundo a desenvolver um programa de combustível alternativo em larga escala em substituição à gasolina (BERTELLI, 1992). Em função disto novas destilarias de álcool surgiram assim como $\circ$ aprimoramento dos processos de fermentação alcoólica. A fermentação pelo sistema em batelada alimentada vem sendo substituida pela fermentação contínua que hoje segundo ZARPELON \& ANDRIETTA (1992), já é responsável pela produção de um quarto dos 12 bilhões de litros de álcool produzido no Brasil anualmente.

Concomitantemente à evolução na indústria sucroalcooleira, trabalhos no sentido de isolar, caracterizar e combater agentes considerados contaminantes de fermentação tem sido feitos, uma vez que estes são causadores de problemas para a fermentação como: consumo de açúcar e etanol, queda de viabilidade e morte das células de levedura devido a toxinas lançadas no meio (ALTERTHUM et al., 1984), perda de células de levedura pelo fundo de dorna ou em centrífuga pela floculação do fermento ( ALMEIDA, 1940; 
Os trabalhos de identificação dos contaminantes ( RODINI, 1985; ROSALES, 1989; GALLO, 1989; OLIVA-NETO, 1990) variam no que diz respeito as bactérias isoladas dos processos fermentativos, provavelmente por estes terem sido realizados em unidades industriais distintas, abastecidas com matéria-prima em diferentes condições. Todavia, em todos eles, as bactérias do grupo Gram-positiva predominaram, sendo que entre estas às do gênero Bacillus e Lactobacillus são a de maior ocorrência.

Esses trabalhos contribuiram para 0 conhecimento da flora contaminante dos processos fermentativos, abrindo assim, caminhos para que outros fossem feitos no sentido de avaliar o desempenho dos antimicrobianos rotineiramente utilizados nas unidades industriais para o combate desses contaminantes.

Baseados nestes fatos este trabalho tem como objetivo contribuir no sentido de determinar uma metodologia para avaliação da Concentração Inibitória Mínima (C.I.M) e Concentração Bactericida Mínima (C.B.M), para bactérias consideradas "problemas" em fermentação alcoólica frente a antimicrobianos utilizados nesta fermentação, assim como, determinar esses valores para as bactérias estudadas.

o trabalho ainda pretende escolher entre as bactérias estudadas, a que mais se presta a servir de microrganismo "teste", quando em teste para dosagem desses antimicrobianos. 


\section{REVISÃO DE LITERATURA}

\subsection{CONTAMINANTES}

\subsubsection{Matéria-Prima}

2.1.1.1. Planta - A cana a qual contém condições favoráveis ao crescimento de microrganismos (açúcar, sais, aminoácidos, etc...) carrega consigo um ecossistema específico. Esta flora é oportunista, isto é, vai crescer quando as condições de defesa da cana estiverem baixas (LOPEZ et al., 1988).

PEDERSON \& HUCKER (1946), citam como habitantes do caldo de cana bactérias do gênero Bacillus, Achromobacter, Flavobacterium, Micrococcus e ainda Escherichia coli e Leuconostoc mesenteroides.

MAYEUX \& COLMER (1960), associaram o estado da folha ao nível de contaminação tendo encontrado em folhas normais contaminação menor do que em folhas "doentes".

Em partes de cana saudáveis, $10^{4}$ a $10^{8}$ de bactérias por grama do produto e $10^{3}$ a $10^{4}$ de fungos foram encontrados por DUCAN \& COLMER (1964). Estes mesmos autores isolaram 198 microrganismos de várias partes da cana-deaçúcar, assim como de plantas de idades diferentes e do caldo. Nestas amostras encontraram vários microrganismos do 
grupo coliforme, como: Escherichia coli, Aerobacter aerogenes e A. cloacae, sendo que o gênero Aerobacter é associado a produção de goma (BERKWITH, 1931).

BRUIJN (1966a), mostrou que o polissacarídeo formado na cana deteriorada é um polímero de glucose, igual a dextrana, sendo este polímero igual ao produto formado pelo Leuconostoc mesenteroides.

KENIRY et al. (1967), descreveram que o estágio de deterioração da cana-de-açúcar que chega na indústria está associado as condições climáticas. Quando o tempo se apresentou seco e frio as condições de deterioração da cana foram mínimas, enquanto que quando o tempo era quente e úmido havia um aumento na taxa de deterioração.

BEVAN \& BOND (1971), em estudos que acompanham a cana do campo à indústria isolaram de cana-de-açúcar sadia 50 diferentes microrganismos sendo Leuconostoc o principal gênero de bactéria encontrado e de leveduras os gêneros Saccharomyces, Torula e Pichia. No mesmo trabalho os autores isolaram Bacillus cereus e Pseudomonas, microrganismos estes, relacionados com o solo e ainda a presença de streptomyces como produtores de ácido, Penicillium capazes de decompor dextranas e finalmente grande número de Actinomyces. Os autores ainda constataram que todos os microrganismos encontrados nos colmos se mostraram em plena atividade e, têm desenvolvimento ótimo nas fendas provocadas pelo crescimento do colmo, assim como metabolizam rapidamente o 
açúcar a temperaturas entre $50-55^{\circ} \mathrm{C}$.

Alford \& MacCleskey ${ }^{1}$ citado por TILBURY (1975), foram alguns dos muitos pesquisadores que isolaram Leuconostoc mesenteroides e L. dextranicum a partir de caldo de cana.

As principais bactérias encontradas na canade-açúcar são Pseudomonas, Flavobacterium, Xanthomonas, Bacillus e Corynebacterium ( Tilbury ${ }^{2}$ citado por TILBURY, $1975)$.

\subsubsection{Práticas Agrícolas}

2.1.2.1. Queima - A prática da queima da canade-açúcar, visa diminuir as impurezas e facilitar o corte, e suas consequências, sob $\circ$ ponto de vista tecnológico e econômico (RIGHI, 1975).

Segundo EGAN (1965), a penetração e colonização de Leuconostoc nos tecidos da cana podem ocorrer após a queima, entretanto a forma de ação não foi suficientemente esclarecida.

ALLEN (1967), relata que em canas queimadas deixadas em pé por 2 dias os teores de açúcar são $3 \%$ maiores que quando comparadas com canas que foram cortadas após a

1 ALFORD, J.A. \& MaCCLESKEY.Some observations on bacteria causing slime in cane juice. Proc. La Acad. Sci. $36-42$, 1942 .

2 TILBURY, R.H. Biodeterioration of harvest sugar cane in Jamaica. PH.D. Thesis. University of Aston in Birmingham, 1970 . 
queima.

A cana depois de queimada parece ficar ainda mais suscetível ao ataque de microrganimos, uma vez que a cera que envolve o colmo, a qual é destruida na hora da queima, exerce ação bacteriostática. A prática da queima que atinge $55-85^{\circ} \mathrm{C}$ não parece ser problema para bactérias, pois 17 diferentes microrganismos foram isolados após 10 minutos da queima da cana sendo predominantemente na forma de bastonetes. Desses isolados 5 foram resistentes ao calor, 2 produziram dextrana e 2 eram formadores de esporos. Passadas 24 horas da queima, microrganismos como Penicillium, Rhizopus, Aspergillus, Torula, Rhodotorula e Candida foram encontrados (BEVAN \& BOND, 1971). Os mesmos autores ainda citam a presença de Leuconostoc após a queima, o qual aumenta em número em função do tempo.

Mayeux ${ }^{3}$ citado por TILBURY (1975), verificou que em canas queimadas, portanto com a cera removida pela ação do calor os microrganismos podem crescer livremente podendo alcançar números na ordem de $10^{9}$ por grama de exsudado dos colmos quentes e úmidos.

FERRARI \& RODELLA (1977), citam que em colmos queimados e deixados inteiros no campo a dextrana se forma após 2 semanas, enquanto que em canas não queimadas a presença de dextrana não foi verificada.

3 MAYEUX, P.A., Some studies on the microbial flora of sugar cane. M.S. Thesis. Lousiana state University, 1960. 
2.1.2.2. Corte - o tipo de corte parece ter influência no número de microrganismos presentes na cana. A contaminação pode ocorrer por materiais de corte (TILBURY, $1968)$.

Na colheita manual a deterioração começa a acontecer passadas 70 horas, enquanto que em canas colhidas mecanicamente este efeito aparece 6 horas após a operação (EGAN， 1965) .

As perdas de sacarose em canas cortadas em toletes são maiores que quando estas estão inteiras na ordem de 2.5ㅇ para cana inteira e 58 para cana em pedaços após 3 dias do corte (ALLEN, 1967).

Os estudos de deterioração de toletes da cana feitos por GENTRY \& GASCHO (1972), mostraram que ocorre diferença no pH dos caldos assim como na pol da cana em função do tamanho dos toletes.

A colheita mecanizada a qual promove seccionamento do colmo em toletes curtos, causa o aumento do grau de infecção dos colmos e consequentemente a deterioração. Aproximadamente uma hora e meia após o corte mecanizado os microrganismos predominantes são: Leuconostoc, Xanthomonas e Aerobacter (KAJI \& CANHOS, 1989).

\subsubsection{Industrializacão}

2.1.3.1. Armazenamento - Outro fator importante é o tempo de armazenamento da cana após o corte e queima. HES (1952), observou a diminuição de 
polarização de caldos provenientes de canas armazenadas em toletes enquanto que pesquisas realizadas por EGAN (1965), verificaram perdas de açúcar e decrescimo do $\mathrm{pH}$ em canas armazenadas.

BRUIJN (1966b), verificou aumento na acidez, diminuição da pureza e aumento da porcentagem de sólidos no caldo em função do tempo de estocagem devido a ação de microrganismo na cana.

EGAN (1971), sugere a eliminação da estocagem da cana cortada nos fins de semana, assim como demoras desnecessárias durante a semana para o processamento desta como forma de se conter a deterioração.

Segundo STURION et al. (1975), o armazenamento de canas cortadas em toletes não deve ultrapassar 24 horas.

TILBURY (1975), estudou o efeito da estocagem no crescimento de bactérias láticas. Este trabalho mostra que até o quarto dia níveis de $10^{7}$ a $10^{8} / \mathrm{ml}$ são alcançados e partir disto ocorre uma decréscimo nestes números. Verificou também que até o quinto dia a flora predominante foi Leuconostoc mesenteroides e $L$. dextranicum e a partir deste devido provavelmente a diminuição do pH a presença de lactobacilos foi observada. Dos 154 isolados de caldo de cana armazenado durante 10 dias, 87 foram identificados como representantes do gênero Leuconostoc entre eles $L$. mesenteroides, $L$ dextranicum e L. paramesenteroides e os 
outros 67 pertencentes ao gênero Lactobacillus entre eles $L$. plantarum e L. casei.

$$
\text { Mayeux } 4 \text { citado por TILBURY (1975), associa }
$$

tempo de armazenamento e condições climáticas ao número de microrganismos, em dias quentes e úmidos a população de bactérias pode atingir niveis de $10 \% \mathrm{~g}$.

\subsubsection{Extracão}

2.1.3.2.1. Água de lavagem - A água de lavagem da cana nas usinas de açúcar tem origem variada dependendo de cada unidade. Sabe-se entretanto que esta é uma via de contaminação do processo.

SERRA et al. (1979), pesquisando em usinas constataram que em unidades que não recirculavam água de lavagem de cana a operação era feita com uma carga microbiana de 10 a 20 vezes menor que em usinas que recirculavam esta água, constataram ainda que depois de chuvas, ocasião onde a água represada é parcialmente renovada a carga microbiana das usinas que operavam com circuitos fechados caiam na ordem de 10 a 20 vezes. Os mesmos autores ainda associam a presença de Bacillus spp na água a presença destes na destilaria.

STUPIELLO (1982), comentà que a prática de recirculação de água de lavagem de cana leva a um aumento dos níveis de contaminação e CONTROLE microbiológico na fabricação de açúcar e álcool (1983), afirma que a população

4 - MAUYEX, P.A., 1960. Some studies on the microbial flora of sugar cane. M.S. Thesis. Louisiana State University. 
microbiana da água de lavagem recirculada pode atingir níveis maiores que $10^{8}$ células/ml. Por outro lado, este autor cita que $\mathrm{o}$ pH é um fator determinante no nivel de contaminação e descreve que em circuitos fechados a contagem de bactérias diminue quando a água de lavagem está com pH entre 10 e 11 e aumenta quando próxima da neutralidade.

LOBO et alli (1987), trabalhando com água de lavagem de unidades industriais obtiveram contagens na ordem de $10^{4}$ e $10^{5} \mathrm{UFC} / \mathrm{ml}$ e afirmam que estas contagens não influenciaram a contaminação encontrada no caldo do primeiro terno das unidades analisadas.

\subsection{Bquipamento - Segundo} TILBURY et al. (1977), as perdas na operação de extração do caldo variam de 1.0 a $2.0 \mathrm{~kg} /$ tonelada de cana, sendo que deste total, 628 estão associadas à atividade microbiana.

MCMASTER \& RAVNO (1977), analisaram a presença de ácido lático em canas recém colhidas e observaram a presença deste somente quando a cana entra na indústria na operação de extração sendo maior em unidades que trabalham com difusor. Esses mesmos autores ainda citam a presença de uma flora termófila esporulada durante o processo de extração do caldo e isolaram desta fase representantes do gênero Bacillus.

Segundo YoKOYA (1989), é normal o crescimento de microrganismo nas moendas e na linha de caldo. Geralmente apresentam formação de gomas nas tubulaçōes, calhas, peneiras 
e paredes de reservatórios. A limpeza física dos equipamentos ajuda a reduzir $\circ$ acúmulo de gomas, mas não evita o crescimento dos microrganismos no caldo que circula nos equipamentos. Esse caldo é um excelente meio de crescimento de muitos microrganismos contaminantes que entram com a cana-de-açúcar. Embora, Leuconostoc esteja constantemente lembrado como causador de problemas na linha de caldo, outros microrganismos são também importantes e em algumas condições podem se tornar mais relevantes. Assim, algumas bactérias Gram-negativas como Klebsiella e Enterobacter, que são habitantes naturais das plantas (incluindo cana-de-açúcar), são capazes de se desenvolver nos equipamentos de extração e transporte de caldo. Outros como Acetobacter, costumam se desenvolver nas áreas onde o contato de ar é bastante intenso como no "cush-cush". Muitas espécies de Klebsiella e Acetobacter são produtoras de biopolímeros de forma gomosa.

Apesar da diversidade da microbiota existente no caldo de cana em função das várias etapas que esta sofre até a obtenção do caldo pronto para a fermentação, nem toda esta flora consegue sobreviver no processo.

Segundo GALLO (1989), as condições peculiares de cada etapa do processo de produção de álcool, selecionarão - desenvolvimento de certos microrganismos. Em função deste fato, especial cuidado tem sido dado as bactérias do gênero Leuconostoc e Lactobacillus (BEVAN \& BOND, 1971; SHARPER et 
al., 1972; TILBURY, 1975) pelo fato destes microrganismos serem acidófilos e resistirem as condições do processo. Entretanto, em função do baixo pH associado a altas temperaturas os mais favorecidos parecem ser os termófilos esporulados como Bacillus stearothermophilus descrito por Mac MASTER \& RAVNO (1975), e representantes do gênero Clostridium descrito por CLARK et al. (1980).

o caldo misto o qual é o resultado de todas as etapas do processo citadas anteriormente, por suas características isto é pH entre 5 e 6 , brix entre 10 e 18, temperatura variando entre $25-30^{\circ} \mathrm{C}$, aminoácidos, sais é um meio ideal para o crescimento de grande variedade de microrganismos (RODINI, 1985). Por outro lado MacMASTER \& RAVNO (1975), relatam que bactérias láticas são as mais adaptadas ao caldo misto, entre elas particularmente Leuconostoc msesenteroides.

BEVAN \& BOND (1971), analisando caldo misto floculado encontraram três tipos de microrganismos: Leuconostoc mesenteroides, levedura (Hansenulla sp ou Pichia sp) e ainda um bastonete curto não identificado. Os autores sugerem simbiose na associação destes três microrganismos onde a levedura contribui com os fatores de crescimento para - Leuconostoc o qual produz ácido lático sendo este utilizado pelo bastonete não identificado Ainda verificaram a sobrevivência de Actinomycetos, Leuconostoc e Bacillus após a clarificação e tratamento térmico a $92{ }^{\circ} \mathrm{C}$. 
LIMA et al. (1974), descrevem que a contaminação no caldo misto alcança níveis de $10^{4}$ tanto para leveduras, enterobactérias assim como Leuconostoc e citam os representantes destes microrganismos: Leuconostoc mesenteroides, L dextranicum, L citrovorum, Aerobacter aerogenes, Paracolobactrum aerogenoides, Pseudomonas sp, Candida fabiani, C. intermedia, C. santamarie, Criptococcus kvetzingii, Hansenula polymorpha, Kloeckera corticis, Rhodhotorula pallida, R. rubra e Saccharomyces uvarum.

Segundo SKOLE et al. (1977), a clarificação do caldo misto ajuda na eliminação da células vegetativas, entretanto formas esporuladas e bactérias produtoras de dextrana continuam viáveis após o tratamento, o que foi constatado por LUCREDI et al. (1984), que demostraram a presença de bactérias em caldo tratado a $115^{\circ} \mathrm{C}$.

SILVA (1988), estudando a microbiota do caldo clarificado, pausterizado e pré-resfriado tanto na entrada como na saída da torre de resfriamento encontrou: Lactobacillus (38\%) e entre eles: L. fermentum, L. confusus, L. viridescens, L. plantarum, L. brevis, L. reuteri e L. buchneri. o mesmo autor descreve ainda como contaminantes bactérias da família Micrococcaceae (23\%) e Leuconostoc (128). Dentro do gênero Leuconostoc 50 \% refere-se a $L$. mesenteroides subsp mesenteroides e ainda bactérias do gênero Bacillus (3) e da família Enterobacteriaceae (18). O mesmo autor verificou que quando o caldo clarificado passa pela 
torre de resfriamento a população microbiana sofre um aumento de 18 a 33 vezes dependendo do meio de cultivo usado para o sub-cultivo. Se MRS ( Man Rogosa Sharpe) ou PCA (Plate Count Agar) respectivamente.

O melaço é um subproduto da produção de açúcar e sua composição inclui alto teor de carbono residual principalmente na forma de sacarose (CAMHI, 1979) e por isto muitas unidades industriais o utilizam na composição do mosto para a fermentação de produção de álcool. souzA et al. (1977), analisando melaço proveniente da fabricação de açúcar cristal e demerara armazenado detectaram a presença 102 e 513 microrganismos por grama de material respectivamente, e identificaram-os como: Bacillus, Enterobacter, Sarcina, Candida melinii, Cryptococcus albidus var.albidus, Cryptococcus infirmominiatus, Debaryomyces cantarelli, Hansenula henricii, H. canadensis, Oosporidium margaritiferum, Rhodotorula graminis, $R$. pallida, sporobolomyces roseus, Torulopsis sp e Torulopsis candida e ainda representantes de fungos filamentosos: Penicillium, Cladosporium, Papulaspora, Monilia e Gliocladium.

Apesar de nem todas as espécies de microrganismos encontradas na obtenção da matéria-prima (caldo) estarem presentes durante outras etapas do processo, estes são de grande importância no que se refere a perdas de açúcares e portanto queda do rendimento industrial assim como formação de produtos que e podem ocasionar problemas 
operacionais.

2.1.3.3. Fermentação - NEVES (1938), foi um dos primeiros pesquisadores a descrever os tipos de fermentação que ocorrem simultaneamente a alcoólica sendo elas: acética, lática, butírica e dextrânica.

ALMEIDA (1940), cita os principais tipos de fermentos que apareçem, promovendo acidentes na fermentação. o autor os classificou como: fermentos lático citando como principal representante deste grupo Bacterium lactis, fermentos butíricos, fermentos acéticos, citando a presença de Bacterium aceti e ainda fermentação do dextrânio associado a presença de Leuconostoc mesenteroides.

GALLI (1961), cita que as principais fermentações "acidentais" são: (i) acética, associada a bactérias do gênero Acetobacter entre elas: A. aceti, A. pasteurianum, A. acetosum, $A$. suboxydans e A. kutzegianum; (ii) levânica, associada a bactérias dos gêneros Bacillus, Streptococcus e Aerobacter; (iii) dextrânica, associada principalmente à Leuconostoc mesenteroides; (vi) lática, associada as espécies de Lactobacillus: L. acidophilus, L. bulgaricus, L. casei, L. leischmanii e ainda streptococcus lactis; e (v) butirica, associada as bactérias clostridium pasteurianum e C. saccharobutyricum.

SERRA et al. (1979; 1980) isolaram de mosto fermentado várias espécies de Bacillus entre estes os autores detectaram a presença de Sporolactobacillus sp.. 
Os gêneros Acetobacter, Lactobacillus, Clostridium, Bacillus, Aerobacter, streptococcus e Leuconostoc são descritos por AMORIM \& OLIVEIRA (1982), como os principais contaminantes da fermentação.

RODINI (1985), estudando mosto fermentado de 17 destilarias que trabalham com mosto constituído de melaço, caldo de cana ou mistura de ambos constatou uma faixa de contaminação na ordem de $10^{7}$ bactérias por ml de amostra. As bactérias Gram positivas se apresentaram como $65.1 \%$ do total sendo que $62.1 \%$ das Gram positivas são pertencentes ao gênero Bacillus incluindo $B$. subtilis, $B$. brevis. Ainda entre as Gram positivas estão incluídas bactérias dos gêneros: Lactobacillus, Leuconostoc, Micrococcus e Planococcus.

PILON \& BERTOLINI (1989), isolaram a partir de vários pontos do processo da fermentação bactérias e as descreveram como: Bacillus, Listeria, Pseudomonas, Clostridium, Lactobacillus e Leuconostoc.

A partir de 5 pontos de amostragem provenientes de várias etapas do processo fermentativo ROSALES (1989), isolou e identificou 222 culturas. Entre estas foram identificados 13 gêneros, 21 espécies e 2 sub. espécies diferentes. Sendo estes contaminantes: L. fermentum, L. brevis, L. confusus, L. plantarum, L. vacinosterccus, $L$. minor, L. fructivorans, L. delbrueckii, Bacillus coagulans, B. firmus, B. subtilis, B. megaterium, sporolactobacillus sp, Leuconostoc mesenteroides sub. sp. mesenteroides, $L$. 
mesenteroides sub. sp. dextranicum e L.mesenteroides, Micrococcus varians, Staphylococcus sp, Acetobacter sp, Xantobacter sp, Pseudomonas sp, Citrobacter sp, Escherichia coli, Acinetobacter calcoaceticus, Enterobacter cloaceae, E. intermedius e $E$. aerogenes. Embora a diversidade dos isolados seja grande o autor cita que os gêneros predominantes no processo foram Lactobacillus (em variedade e número) e Leuconostoc (em número).

GALLO (1989), isolou e identificou de amostras de leite de levedura diluído antes e depois de tratamento ácido, do mesmo leite de levedura após adição e ação do ácido sulfúrico, do mosto adicionado ao mesmo leite de leveduras amostrado e do vinho final da mesma dorna de fermentação 334 culturas bacterianas. A microbiota predominante foi Grampositiva (98.528) sendo que entre estes 87.768 eram bastonetes e de não esporulados (73.958). O gênero Lactobacillus foi o mais frequente (59.75\%) entre eles: $L$. fermentum, L. helveticus, L. plantarum, L. animalis, L. buchneri, L. acidophilus, L. vitulinus, L. viridescens, $L$. amylophilus, L. agilis, L. reuteri, L. delbrueckii subsp. lactis, L. murinus, L. delbrueckii subsp. bulgaricus, $L$. coryniformis subsp. torquens e $L$. sake. Do total dos isolados 26.588 pertencia ao gênero Bacillus e entre eles as seguintes espécies: $B$. coagulans, B. stearothermophilus, B. megaterium, $B$. brevis, B. lentus e B. pasteurii. Ainda entre os isolados foram caracterizadas bactérias dos gêneros: Staphylococcus 
(8.768), Micrococcus (1.56\%), linhagens da família Enterobacteriaceae (1.48\%), Pediococcus (1.26\%) e Streptococcus $(0.70 \%)$.

KAJI (1989), estudando a associação de Leuconostoc mesenteroide subsp. mesenteroides e Lactobacillus fermentum a fermentação alcoólica sugere que após o término da fermentação conduzida em laboratório apenas o Lactobacillus fermentum foi recuperado através de contagem de placas enquanto que isto não ocorreu para $L$. mesenteroides. o mesmo autor ainda sugere que $L$. mesenteroides não causa distúrbios significativos nas dornas de fermentação uma vez que este foi afetado por concentrações mais baixas de álcool que as encontradas nas dornas em condições industriais.

SEKI et al. (1989), estudando os deterioradores de fermentação de melaço em indústrias produtoras de álcool da Tailândia isolaram 89 culturas láticas de mosto fementado entre elas: Lactobacillus buchneri, L. casei subsp. casei, L. casei subsp. rhamnosus, L. cellobiosus, L.mali e L. reuteri, sendo que $L$. reuteri e L. cellobiosus foram os que predominaram.

OLIVA-NETO (1990), trabalhando com amostras de "leite de levedura" sem tratamento ácido encontrou: Lactobacillus fermentum (628), L. murinus (98), L. vaccinostercus (9\%), L. plantarum (2\%) e Leuconostoc (2\%). O mesmo autor afirma que as cepas isoladas apresentaram-se resistentes a $78 \mathrm{v} / \mathrm{v}$ de etanol e 648 resistiram a 108 , 
demostrando adaptação ao ambiente alcoólico e que a caracteristica de floculação do fermento foi manifestada em $67 \%$ das cepas testadas.

\subsection{CONSEQUENCIAS DOS CONTAMINANTES NO}

\section{PROCESSO FERMENTATIVO}

2.2.1. Perdas no rendimento - o rendimento da fermentação é expresso em quantidade de produto formado (etanol) por unidade de açúcar consumido (YOKOYA, 1989). Em função disto todo açúcar que não é convertido em álcool e sim em outros produtos faz com que ocorra diminuição neste rendimento.

TANTAOI (1952), avaliando perdas com a formação de dextrana em unidades industriais relata que estas podem alcançar números perto de $3 \mathrm{~kg} /$ ton. cana e TILBURY et al. (1977), cita que $62{ }^{\circ}$ das perdas de açúcar estão associadas aos microrganismos contaminantes.

SERRA et al. (1979), constataram que a presença de bactérias que produzem mucilagem pode acarretar queda no rendimento de fermentação na ordem de $15 \%$.

AMORIM et al. (1981), associam às bactérias contaminantes perdas a niveis de 55 웅 do valor teórico.

Para AMORIM \& OLIVEIRA (1982), o não controle dos cocos pode ocasionar indiretamente um abaixamento no rendimento da fermentação por dois motivos: aumento da viscosidade do vinho ocasionando uma maior perda de fermento no vinho centrifugado e maior consumo de açúcar, desviando 
este da produção de álcool.

ALTERTHUM et al. (1984), mostram que quedas no rendimento alcoólico variáveis de 14 a $90 \%$ do teórico, foram verificadas quando a concentração bacteriana atinge concentrações de $10^{8}$ a $10^{9}$ células/ml.

CRUZ et al. (1985), conseguiram valores de 10 a 408 menores no rendimento alcoólico em fermentações contaminadas aos niveis de $10^{7}$ a $10^{8} \mathrm{cel} / \mathrm{ml}$.

KAJI (1989), estudando fermentação alcó́lica usando duas linhagens diferentes de levedura $S$. cerevisiae (NRRL Y-2342 e FTPT 0472) com adição de Leuconostoc mesenteroides subsp. mesenteroides e Lactobacillus constata que em presença de $L$. mesenteroides subsp. mesenteroides o rendimento foi reduzido $(6.8$ e 3.28 para linhagens NRRL Y2342 e FTPT 0472, respectivamente) quando comparado a fermentações sem este microrganismo. Já na presença de Lactobacillus ocorreu aumento de rendimento alcoólico máximo (68) em relação as culturas puras testadas. Porém, a produtividade global máxima foi menor na fermentação por $S$. cerevisiae NRRL Y-2342 (6.28) e maior na fermentação pela linhagem FTPT 0472 (11.3ㅇ).

Segundo KHAN \& HOQ (1990), fermentações conduzidas em presença de $5.05 \times 10^{6}$ bactérias sendo que $5 \times 10^{3}$ eram produtoras de ácido apresentaram rendimento 11.48 menor que quando estas não estavam presentes.

2.2.2. Metabólicos produzidos - Os metabólicos 
produzidos pelas bactérias contaminantes ocasionam não só perdas no rendimento como inibição da levedura por estes produtos formados e também problemas operacionais.

Muitos autores têm se preocupado com problemas operacionais normalmente associados a presença de gomas (EGAN， 1965; TILBURY,1968 FOSTER,1969; SUTHERLAND \& PATON,1969; TILBURY,1971; BEVAN \& BOND,1971).

BOVI \& MARQUES (1982), citam que os polímeros produzidos por contaminantes não são utilizados pela levedura podendo ser considerados como material inerte.

JOLLY \& PRAKASH (1987), relatam que a dextrana produzida por bactérias deterioradoras da cana podem provocar - bloqueio das centrífugas nas refinarias, e que desta dextrana produzida 50\% é insolúvel, portanto não sendo eliminada no processo de clarificação.

As fermentações secundárias que ocorrem paralelamente a alcoólica têm sido estudadas desde os primeiros trabalhos associados a produção de álcool (NEVES,1938; ALMEIDA, 1940; GALLI,1961).

GUILLILAND \& LACEY (1964), estudaram o efeito de metabólicos sobre a levedura colocando esta em associação com Acetobacter. Quando esta foi colocada na proporção $1: 1$ a levedura não consegue crescer, quando em 3:1 as leveduras morrem em 5 dias e na proporção 10:1 estas morrem em 3 dias. AMORIM \& OLIVEIRA (1982), citam que a presença de ácido lático e outros ácidos orgânicos são os responsáveis 
pelo fracasso da fermentação.

MAIORELLA et al. (1983), estudaram a inibição da levedura por diferentes compostos e verificaram que esta varia com o tipo e composição do composto presente. Assim, para o ácido acético esta é de de $0.9 \mathrm{~g} / \mathrm{l}$ para o ácido fórmico é de 1.2g/1, enquanto que para ácido lático e para - 2,3 butanodiol essas concentrações são bem maiores, de $17 \mathrm{~g} / 1$ e $55 \mathrm{~g} / 1$ respectivamente.

GUTIERREZ et al. (1991), citam que os ácidos acético e lático podem ser formados por bactérias contaminantes e leveduras. O mesmos autores relatam que em fermentações alcoólicas realizadas com baixa concentração de fermento o aumento da concentração de ácido acético ocasiona menor aumento da massa celular, redução da formação de glicerol e aumento do etanol produzido.

2.2.3. Floculacão - A floculação acarreta problemas cinéticos, ou seja, diminue a velocidade de fermentação, uma vez que diminue a área de contato entre a levedura e substrato, e ainda problemas operacionais tais como: aumento de fundo de dorna e dificuldades de operação das separadoras centrifugas.

SERRA et al. (1979), associam floculação a presença de bactérias do gênero sporolactobacillus e explica - mecanismo desta devido a presença de uma capa protéica, de natureza gelatinosa, acarretando assim a fixação mecânica das células de levedura. 
ROSALES et al. (1989), em estudos de associações de Saccharomyces carlbergensis com: Leuconostoc mesenteroides subsp. mesenteroides, Bacillus subtilis, Lactobacillus confusus e Aerobacter aerogenes constataram que todas estas bactérias promovem floculação da levedura entretanto o tamanho e a sedimentação dos flocos assim como a dissociação com tratamento ácido foram diferentes para cada tipo de bactéria estudada.

YOKOYA (1989), aponta como agente de floculação linhagens de Lactobacillus, e ainda defende a tese que não somente bactérias são promotoras de floculação mas também algumas linhagens de leveduras. Em trabalhos mais recentes YOKOYA \& OLIVA-NETO (1991), estudaram entre outros fatores a influência de Lactobacillus fermentum no fenômeno de floculação. Concluiram que existem linhagens que são promotoras de floculação e que existem outras linhagens que não a promove, e ainda que a floculação está associada à presença das células bacterianas uma vez que, quando estas são retiradas do meio de cultivo o sobrenadante não apresenta poder floculante. Os autores acreditam que: (a) exista uma relação quantitativa de células de levedura e de bactéria que resulta na máxima floculação sendo que esta varia com a concentração celular; (b) a floculação por bactérias é estimulada por íon cálcio e inibida a valores de pH extremos; e (c) O fator responsável pela capacidade de floculação de levedura é termolábil e sensível a proteases indicando ser 
este de natureza protéica.

\subsection{ANTIMICROBIANOS NA FERMENTAÇÃO}

VAUGHAN (1934), foi um dos primeiros pesquisadores a descrever formas de controle da infecção em fermentação alcoólica. O autor descreve que a acidez no mosto auxilia a levedura na primeira fase do seu trabalho bioquímico e ainda se usado de forma racional proporciona ao meio de cultura o ambiente preferido pela levedura uma vez que os demais "germes" preferem o meio alcalino ou ligeiramente alcalino. O mesmo autor ainda cita o processo EFFRONT, onde são utilizados para o controle da fermentação sais como: fluoreto de amônio e sódio, sulfato de cobre e formol.

AQUARONE (1959), estudou a influência da penicilina e tetraciclina na fermentação de mosto de melaço e concluiu entre outros: (a) tetraciclina em concentrações de 15mg/l parece inibir a contaminação por Leuconostoc; tetraciclina em concentrações de até $30 \mathrm{mg} / 1$ não afetaram a fermentação nem a multiplicação do fermento; (c) concentrações de até $5000.000 \mathrm{U}$ de penicilina por litro de mosto não influenciaram a fermentação; e (d) a utilização de penicilina na fabricação do álcool por fermentação pelo processo clássico traz grandes vantagens econômicas para a indústria.

AQUARONE et al. (1966), verificaram a ação do ácido sulfúrico e penicilina $G$ potássica na fermentação e 
concluiram que a penicilina é mais vantajosa, principalmente se utilizada no processo todo, incluindo a pré-fermentação. AQUARONE (1968), trabalhou com penicilina, pois segundo este autor este antibiótico apresenta baixo custo e ainda super produção no Brasil e também com cloranfenicol uma vez que este era produzido no Brasil, foi testado por vários pesquisadores, é estável ao calor muito mais que a penicilina e além disto é estimulante da fermentação. Os resultados que o autor relatou foram: 250 unidades de penicilina por litro associadas a diversas quantidades de cloranfenicol, parecem ser menos desinfetantes em fermentações alcoólicas que concentrações inferiores desses antibióticos, a associação de 125 unidades de penicilina com $0.125 \mathrm{mg}$ de cloranfenicol por litro revelou-se a mais econômica das estudadas. Usando o processo MELLE BOINOT com emprego de penicilina e cloranfenicol como desinfetante, inclusive em associações, para a fabricação de aguardente de caldo de cana, obteve-se um maior rendimento em álcool, "vinhos" de menor acidez e ainda um tempo menor de fermentação.

BEVAN \& BOND (1971), discutem os custos e benefícios de biocidas utilizados na indústria sucroalcooleira. Os autores acreditam que esses produtos destroem grande quantidade da população microbiana, entretanto estes são caros e requerem aplicação constante. No trabalho cita-se que quando estes biocidas são utilizados 
devem ser feito de forma a promover o controle dos microrganismos deterioradores, levando em consideração as propriedades dos mesmos.

AYALA et al. (1977), estudaram a ação de: (a) produto orgânico clorado; (b) formaldeído; (c) cianoditioimicarbonato dissódico em associação com Nmetildiocarbamato de potássio e etilenodiamina; e (d) três produtos a base de quaternário de amônio sobre o caldo de cana. Os autores analisaram brix, pol, pureza, açúcares redutores e pH e indicam a utilização de produto orgânico clorado em doses de 1000 ppm para o controle dos microganismos deterioradores.

FRANCO (1978), aconselha o uso de 1.5 a $2.0 \mathrm{~g} / \mathrm{m}^{3}$ de penicilina ácida como tratamento de choque.

SATTO et al. (1980), trabalhando em estudo do efeito de sais de lucensomicina e sulfato de aminosidina em concentrações de $0.4 \mathrm{mg} / \mathrm{ml}$ e de penicilina na concentração de 1000 UI/l concluiram que a penicilina é mais aconselhável no processo como um todo, uma vez que esta manteve-se com ação superior em todos os ensaios realizados.

Estudos comparando a ação de penicilina $V$ ácida com outros biocidas ditos não convencionais $(2$ tiocianometiltio) benzotiazol e hidroxietil 2,3 dibromopropionato em associação com 2 (tiocianometiltio) foram estudos por FURLETTI et al. (1981), para verificar a influência destes no rendimento alcólico. Os autores 
obtiverem rendimentos maiores para todos os produtos testados quando comparado ao controle.

CRUZ et al. (1985), trabalharam com duas bactérias Gram positivas isoladas de 2 diferentes unidades de produção de etanol. Apenas a isolada de uma das unidade a qual era de forma cocoide foi controlada com adição de 500UI de penicilina V-ácida, enquanto que o bacilo não pode ser controlado.

Segundo BOONSONG \& WIWUTI (1985), produtos a base de quaternário de amônio podem inibir Leuconostoc mesenteroides, Lactobacillus cellobiosus, Bacillus subtilis, Lactobacillus fermentume streptococcus sp. quando utilizados em concentrações de 10-20ppm.

OLIVEIRA et al. (1987), testando a ação de seis bactericidas sobre bacterias e levedura obtiveram os seguintes resultados: (a) quaternário de amônio na concentração de 48.98 de matéria ativa inibiu Bacillus subtilis $\mathrm{C}_{6}$ e Leuconostoc Rec na dose de 50ppm, Streptococcus 2223 na dose de $75 \mathrm{ppm}$ e não afetou o crescimento de coliforme $\mathrm{C}_{5} 1$ e Lactobacillus $102 \mathrm{~b}$ e Saccharomyces cerivisiae em dose até 100ppm; (b) quaternário de amônio na concentração de 7.578 de matéria ativa não inibiu nenhum dos microrganismos estudados (Bacillus subtilis $\mathrm{C}_{6}$, Leuconostoc Rec, Streptococcus 2223, Lactobacillus 102b, coliforme $\mathrm{C}_{5} 1$ e Saccharomyces cerevisiae) em dose de até 100ppm; (c) quaternário de amônio na concentração de $50.75 \%$ de matéria 
ativa inibiu Bacillus subtilis $C_{6}$ na dose de $100 \mathrm{ppm}$, Leuconostoc Rec, coliforme $\mathrm{C}_{5} 1$ e streptococcus 2223 na dose de $75 \mathrm{ppm}$ e não inibiu o crescimento de Lactobacillus $102 \mathrm{~b}$ e de Saccharomyces cerevisiae na dose de 100ppm; (d) organo sulfuroso D inibiu Bacillus subtilis $C_{6}$ na dose de $100 \mathrm{ppm}$ sendo que Leuconostoc Rec, coliforme $\mathrm{C}_{5} 1$, Streptococcus 2223 Lactobacillus 102b e Saccharomyces cerevisiae não foram inibidos em doses de até 100ppm; (e) organo sulfuroso E inibiu Bacillus subtilis $\mathrm{C}_{6}$ e Saccharomyces cerevisiae em doses de 50ppm, Leuconostoc Rec e Streptococcus 2223 nas doses de $25 \mathrm{ppm}$ e não inibiu Lactobacillus $102 \mathrm{~b}$ e coliforme $\mathrm{C}_{5} 1$ com dose de até $100 \mathrm{ppm}$;e (f) organo sulfuroso $\mathrm{F}$ inibiu Bacillus subtilis $\mathrm{C}_{6}$ na dose de $75 \mathrm{ppm}$, Streptococcus 2223 na dose de 25ppm, Saccharomyces cerevisiae com 100ppm e não inibiu Leuconostoc Rec, coliforme $\mathrm{C}_{5} 1$ e Lactobacillus 102b nas doses de até 100ppm.

BRAUNBECK (1988), estudou o efeito de fenol não clorado, derivado de triazina, quaternário de amônio 708, quaternário de amônio 50 ( 2 marcas comerciais diferentes) e dióxido de cloro sobre as leveduras M-300-A (TA-79), IZ 1904 e Fleischmann em concentrações de $40 \mathrm{ppm}$ e segundo o autor não foi observado efeito acumulativo de biocida durante os três ciclos de fermentação realizados, foi verificado um melhor rendimento fermentativo quando $\circ$ biocida controlou 0 brotamento e uma diminuição na viabilidade não afetou o rendimento. 
EGUCHI (1989), cita como os principais agentes de controle antimicrobiano utilizados nas usinas de açúcar e álcool: fenois e compostos fenólicos, cloro e compostos clorados, quaternários de amônio, aldeídos e antibióticos.

GALLO (1989), observou a redução média de 44.558 da flora bacteriana quando o fermento recebeu ácido sulfúrico por aproximadamente 2 horas a um pH igual a 2.0 . ONNA \& HASHIMOTO (1989), trabalharam com ação de dimetilditilcarbamato sódico e etilenbisditiocarbamato dissódico em unidade industrial e acreditam que se pode atingir economias na ordem de US\$1.88 por tonelada de açúcar uma vez que este produto reduz a ação da microbiota deterioradora.

RODINI (1989), testou e concluiu sobre bactérias dos gêneros: Micrococcus, Pediococcus, Leuconostoc e Acinetobacter, penicilina e pentaclorofenol e concluiu que frente a penicilina Acinetobacter cresceu em concentrações de até 40ppm, já em pentaclorofenol ocorreu crescimento em concentrações de $100 \mathrm{ppm}$. Quanto as outras bactérias testadas, estas resistiram até $40 \mathrm{ppm}$ de penicilina mas foram eliminadas por volta desta mesma concentração (40ppm) de pentaclorofenol.

ROSALES (1989), avaliou dez produtos químicos de uso rotineiro sobre quatro espécies diferentes de bactérias (Bacillus subtilis, Leuconostoc mesenteroides subsp. mesenteroides, Lactobacillus confusus e Enterobacter 
aerogenes), mas que eram produtoras de biopolímeros. A avaliação foi feita por disco de celulose embebido no produto com concentração final de $30 \mathrm{ppm}$. Desses 10 o autor escolheu quatro e para essa escolha foram avaliados os seguintes parâmetros: * estabilidade frente a matéria orgânica, * pouca ou ausência de ação sobre a levedura, * maior espectro de ação perante os contaminantes. Escolhe-se os seguintes:

* organo sulfuroso, * compostos orgânicos triclorados, * composto de quaternário de amônio, * penicilina Vpotássica. Esses compostos foram testados nas bactérias isoladas e no "pool" dessas e em associação com levedura utilizando para isto técnica de plaqueamento. Os resultados foram: 1 - penicilina, orgânicos triclorados e organo sulfuroso afetam a viabilidade de Leuconostoc mesenteroides subsp. mesenteroides quando associado à levedura; 2 penicilina e quaternário de amônio diminuiram as contagens de Bacillus subtilis e na associação com leveduras; 3 penicilina e organo sulfuroso apresentam ação sobre Aerobacter aerogenes; 4 - penicilina e orgânicos triclorados reduziram o número de UFC/ml de Lactobacillus confusus;e 5 nenhum dos quatro produtos afetou a viabilidade das leveduras. o mesmo autor faz menção a adição de ácido sulfúrico como prática de forma de controle das infecçōes da fermentação alcoólica e que este inibi grande parte das bactérias sem contudo inibir as leveduras, e constatou que este tratamento ácido reduz parcialmente bactérias dos 
gêneros Lactobacillus e Leuconostoc.

GAYLARDE \& LATORRE (1990), citam que as infecções do processo devem ser tratadas com microbiocidas de largo espectro sem risco para a fermentação, ou seja as leveduras devem ser o menos possível afetadas e ainda que esses devem ser altamente efetivos contra os contaminantes bacterianos e não devem ser perigosos ao ambiente assim como aos operadores do processo.

RAVELO et al. (1991), estudaram a viabilidade da utilização de um produto a base de amina de diferentes graus de alquilação no tratamento de canas após a queima. Os autores utilizaram como indicadores de deterioração a formação de polissacarídeos e oligossacarideos em caldo de cana e segundo eles com aplicações baixas do produto (10 a 100 pm) esta deterioração pode ser evitada por mais de 3 dias se aplicado a cana cortada mecanicamente e afirmam ainda que este produto não é tóxico tem baixo custo e pode ser obtido a partir de melaço.

Alguns autores têm se preocupado em encontrar métodos alternativos para o tratamento de controle da infecção como por exemplo utilização de sistema de ultra som (MASSON \& BALBO, 1991) ou ainda radiação gama (ACOSTA \& LODOS, 1982; VAN ZELLER et al., 1984).

\subsection{MODO DE AÇÃO DOS ANTIMICROBIANOS}

Segundo EGUCHI (1989), os principais antimicrobianos químicos são: fenol e compostos fenólicos, 
alcoóis, halogênicos e halogenados, metais pesados e seus compostos, corantes, detergentes, compostos de amônia quartenária, aldeídos e agentes gasosos.

Entre estes os usualmente utilizados na indústria sucroalcooleira e seu modo de ação são:

2.4.1. Compostos fenólicos - Estes compostos quando em altas concentrações agem penetrando e rompendo a parede celular do microrganismo resultando na precipitação das proteínas situadas no protoplasma. Quando em concentrações baixas estes agem de forma a promover a inativação de enzimas essenciais para a manuntenção da célula (EGUCHI, 1989).

2.4.2. Compostos clorados - A ação destes compostos sobre os microrganismos tem sido relatado por vários pesquisadores e muitas teorias tem sido descritas em literatura referente a esses compostos. LAWRENCE \& BLOCK (1968), descrevem algumas dessas teorias: (a) ocorre liberação de oxigênio nascente o qual vai se combinar com componentes do protoplasma celular destruindo o microrganismo; (b) combinação do cloro com proteínas da membrana celular formando N-cloro, o qual interfere no metabolismo celular levando assim a morte do microrganismo; (c) o cloro consegue modificar a membrana celular permitindo a difusão do conteúdo do interior da célula para o meio externo;e (d) inibição de enzimas "chaves" das reações celulares.

Existem muitas outras teorias citadas na 
literatura sobre o mecanismo de ação desses compostos clorados, entretanto todos concordam que a ação desses compostos é rápida ocorrendo logo após adição deste ao meio.

2.4.3. Quaternário de amônio - EGUCHI (1989), relata a ação desses compostos sobre os microrganismos. Entre outras formas de ação o autor descreve: desnaturação de proteínas, interferência com a glicólise e danos na membrana.

2.4.4. Aldeidos - Normalmente utilizados na forma formaldeído e glutaraldeído. A forma de ação do formaldeído parece estar relacionada com o crescimento desbalanceado, onde funções especifícas são bloqueadas, como por exemplo sintese de parede celular, ou ainda pelo acúmulo de substância celular, que inibe a formação de metionina a qual tem função vital para a célula. Enquanto utilizado na forma de glutaraldeído esses tem atuação nas proteínas superficiais da célula.

$$
\text { 2.4.5. Antibióticos - Segundo EGUCHI (1989), }
$$

antibióticos são tipos especiais de agentes quimioterapêuticos geralmente obtidos a partir de metabólicos de microrganismos vivos e que em quantidades muito pequenas podem matar ou inibir outros microrganismos. Os antibióticos podem ser divididos levando-se em conta o mecanismo de ação, tendo visto a grande diversidade dessas substâncias.

No que se refere a processos fermentativos os antibióticos mais utilizados são tetraciclina, cloranfenicol, penicilina e virginiamicina, sendo este último introduzido 
recentemente no setor. As formas de ação destes assim como microrganismos produtores são respectivamente: inibem a ação de cofatores enzimáticos, Streptomyces (tetraciclina); inibe síntese proteica, streptomyces venezuelae (cloranfenicol); inibição da biossíntese de constituintes essenciais da membrana, interferindo no transporte ativo da mesma, Penicillium notatum (penicilina);e inibição de síntese protéica, streptomyces virginiae (virginiamicina).

\subsection{METODOLOGIA PARA AVALIAÇĀO DE ANTIMICROBIANOS}

Apesar de muitos trabalhos terem sido feitos no sentido da avaliação dos antimicrobianos disponíveis no mercado, o setor sucroalcooleiro é deficente no que diz respeito a padronização de metodologia para o teste destes produtos,assim como qual dos microrganismos que deve ser adotado com "teste".

CEREDA et al. (1981), sugerem métodos turbidimétricos para avaliar o desempenho de antimicrobianos, e sugere como microrganismo "teste" Leuconostoc mesenteroides.

OLIVEIRA et aI. (1987), fizeram extenso trabalho no sentido de normatização de técnica para avalição de bactericidas e recomendam a utilização de 2 metodologias, uma em meio de cultivo sólido (M.S) utilizando para isto a técnica de "Lederberg \& Lederberg", e a outra metodologia consiste na utilização do mesmo meio na forma líquida onde se trabalha com um "coquetel de bactérias". 
Segundo COSTA et al. (1987), pH e acidez sulfúrica são bons indicadores para a avaliação de biocidas em caldo primário.

Embora a literatura seja deficiente no que diz respeito a metodologia para avaliação de antimicrobianos utilizados no setor sucroalcooleiro o mesmo não ocorre na área médica onde inúmeros estudos têm sido desenvolvidos neste sentido e podem ser tomados como base para se avaliar antimicrobianos para outras áreas.

Segundo ROCHA et al. (1972), a sensibilidade dos microrganismos a drogas, pode ser investigada em rotina, por métodos de diluição e de difusão. Nos primeiros, concentrações previamente determinadas da droga são incorporadas ao meio de cultivo, o microrganismo é semeado e o sistema incubado em temperatura e atmosfera adequadas. Depois de um período de tempo definido, verifica-se a menor concentração da droga que foi capaz de impedir o crescimento do microrganismo. O meio pode ser líquido ou sólido. No segundo grupo de métodos, deixa-se a droga difundir no meio de cultivo solido a partir de reservatorio, que pode ser um orifício, valeta, tira ou um disco de papel de filtro ou mesmo uma pastilha e depois o microrganismo é uniformemente semeado no meio de cultivo, e o crescimento verificado apos 18-24horas. O significado da inibição é interpretado de acordo com a técnica usada. Tanto os métodos de diluição como os de difusão, mas particularmente a técnica de diluição em 
meio liquido podem ser complementadas no sentido de informarem se a droga é bacteriostática ou bactericida (ROCHA et al. 1972). 


\section{MATERIAL E METODOS}

\subsection{MATERIAL}

\subsubsection{Bactérias}

Sem ignorar a importância das bactérias Gram negativas no consumo de açúcar, contido no mosto destinado a produção de álcool por via fermentativa utilizando leveduras, - grupo das bactérias Gram positivas é o que mais problemas traz para este processo. Isto pode ser associado ao fato da constituição da parede celular das bactérias Gram negativas ser rica em lipídios, os quais são facilmente solubilizados pelo álcool, produto este sempre presente nas dornas de fermentação. Isto tem sido constatado por diversos pesquisadores, os quais isolaram uma microbiota predominantemente Gram positiva das unidades produtoras de álcool.

RODINI ( 1985 ), identificou de mosto fermentado de várias unidades industrias 66 colônias sendo que destas 71.1용 apresentavam características do grupo Gram positivo. SILVA (1988), mesmo trabalhando apenas com o caldo de cana isolou uma flora predominantemente Gram positiva (88용). Já ROSALES (1989), trabalhou com amostras provenientes do processo fermentativo e tomou o cuidado de 
trabalhar com meios que promovessem condições de crescimento de bactérias do grupo Gram negativo. Mesmo assim dos 222 isolados $75.63 \%$ foram pertencentes ao grupo das bactérias Gram positivas. Outro autor que trabalhou com amostra do processo fermentativo foi GALLO (1989), e encontrou que 98. 52 용 da microbiota era Gram positiva.

De posse destas informações optou-se então por trabalhar com bactérias do grupo Gram positivo.

Entre as bactérias Gram positivas optou-se por trabalhar com bactérias dos gêneros: Bacillus, Lactobacillus e Leuconostoc, uma vez que estas são citadas como associadas a problemas nas unidades produtoras de álcool.

Do gênero Bacillus trabalhou-se com as espécies $B$. brevis (isolados de processos fermentativos por RODINI, 1985 ; GALLO, 1989 ) B. megaterium (isolados de processos fermentativos por RODINI, 1985 ; GALLO, 1989 ; ROSALES, 1989), B. coagulans (isolados de processos fermentativos por GALLO, 1989 ; ROSALES, 1989), B. subtilis (isolados de processos fermentativos por RODINI, 1985 ; ROSALES, 1989 ).

Do gênero Lactobacillus trabalhou-se com as espécies: L. buchneri (isolados de processos fermentativos por GALLO, 1989 ; ROSALES, 1989), L. fermentum ( isolados de processos fermentativos por GALLO, 1989 ; ROSALES, 1989), L. plantarum (isolados de processos fermentativos por GALLO, 
$1989 ;$ ROSALES, 1989 ).

Em relação ao gênero Leuconostoc, trabalhou-se com o espécie L. mesenteroides (isolados de processos fermentativos por ROSALES, 1989).

A procedência destas bactérias foram:

Bacillus subtilis (RODINI, 1985);

Bacillus megaterium (RODINI, 1985);

Bacillus brevis (GALLO, 1989);

Bacillus coagulans (GALLO, 1989);

Lactobacillus fermentum (GALLO, 1989);

Lactobacillus plantarum (C.C.T.0580);

Lactobacillus buchneri (GALLO, 1989); e

Leuconostoc mesenteroides (C.C.T. 1062).

Estas foram obtidas a partir de culturas liofilizadas.

\subsubsection{Antimicrobianos}

Os antimicrobianos utilizados foram os de uso rotineiro nas indústrias de álcool, cloranfenicol, fermacol, penicilina $V$ potássica, quaternário de amônio e virginiamicina.

As concentrações empregadas foram aquelas recomendadas para o combate aos contaminantes nas unidades industriais (DR) e ainda, duas doses abaixo da recomendada e quatro doses acima e ainda um controle.

A dosagem final dos antimicrobianos foi feita 
a partir de uma única solução estoque para cada um dos produtos testados. O solvente utilizado foi a água esterilizada (no caso de virginiamicina foi utilizado álcool para a obtenção de uma pasta antes de se adicionar a água). As dosagens finais foram feitas utilizando-se pipetas de alta precisão (GILSON P20 e P200).

Os antimicrobianos e as concentrações utilizadas se encontram na Tabela 1.

Tabela 1 - Doses utilizadas para cada um dos antimicrobianos testados.

\begin{tabular}{lc}
\multicolumn{1}{c}{ ANTIMICROBIANO } & CONCENTRAÇÃO(PPM) \\
\hline CLORANFENICOL & $0.25 ; 0.5,1^{*} ; 2 ; 4 ; 8$ e 16 \\
FERMACOL & $0.25 ; 0.5 ; 1^{*} ; 2 ; 4 ; 8$ e 16 \\
PENICILINA V POTÁSSICA & $0.25 ; 0.5 ; 1^{*} ; 2 ; 4 ; 8$ e 16 \\
QUATERNARIO DE AMONNIO & $1.5 ; 2.5 ; 5^{*} ; 10 ; 20 ; 40$ e 80 \\
VIRGINIAMICINA & $0.25 ; 0.5 ; 1^{*} ; 2 ; 4 ; 8$ e 16
\end{tabular}

* Dose recomendada

\subsubsection{Meio de Cultivo}

Para todos os ensaios utilizou-se o meio "De Man, Rogosa, Sharpe" (MRS Difco 0881-01-3), tanto na forma sólida como líquida.

Este meio de cultivo foi escolhido uma vez que mostra ser adequado para o crescimento de todas as bactérias estudadas.

Utilizou-se ainda, para a manutenção das bactérias "LITMUS MILK" (Leite tornasolado Difco 0107-01-1). 


\subsection{METODOS}

\subsubsection{Manutenção das bactérias}

A partir da reativação dos liofilizados e crescimento das bactérias, estas foram inoculadas em $2.5 \mathrm{ml}$ de"LITMUS MILK" e congeladas imediatamente $\left(-18^{\circ} \mathrm{C}\right)$, para que os metabólicos produzidos pelas bactérias não interferissem na manuteção destas. O número de tubos foi feito no sentido de serem suficientes para que a cada novo ensaio um lote de bactérias fosse utilizado, e que todos os ensaios fossem feitos com as bactérias provenientes do liofilizado original ( Figura 1).

Foram preparados 30 tubos para cada uma das oito bactérias.

\subsubsection{Preparo dos Antimicrobianos}

Os antimicrobianos foram pesados em condições assépticas e tranferidos para balões volumétricos deixados por 1 hora em luz ultravioleta. A partir disto os volumes foram ajustados com água estéril e tranferidos para garrafas de diluição de leite previamente esterilizada.

A partir das soluções estoque os antimicrobianos foram dosados com micropipeta de precisão em função da concentração final que se desejava obter (Figura 2) . 


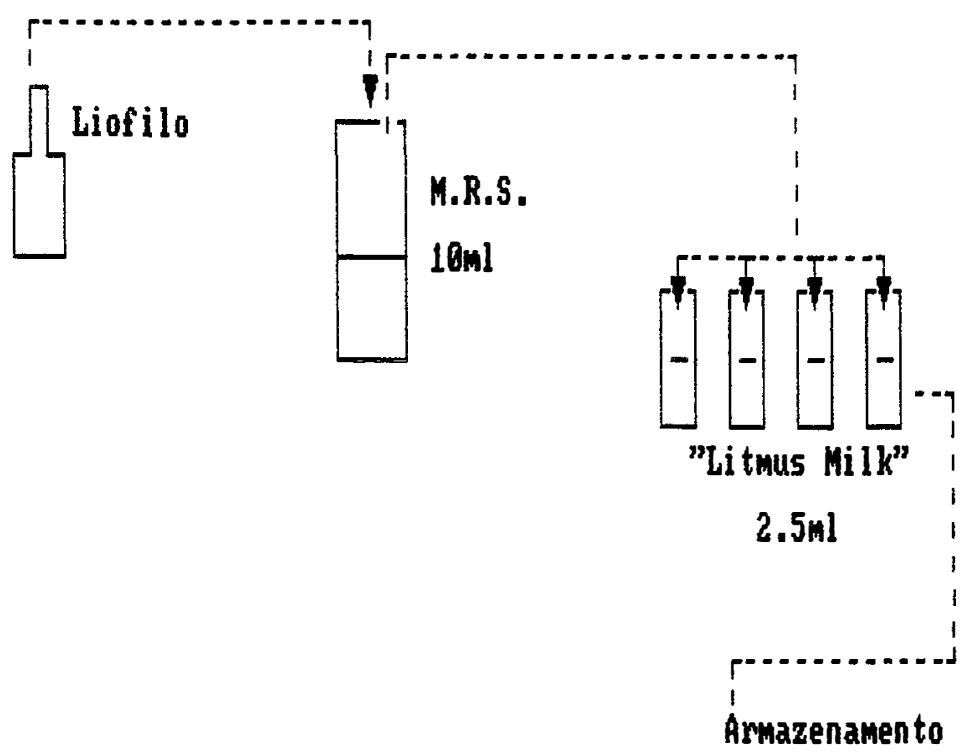

$\mathrm{a}-18^{\circ} \mathrm{C}$

Figura 1 - Manutenção das bactérias.

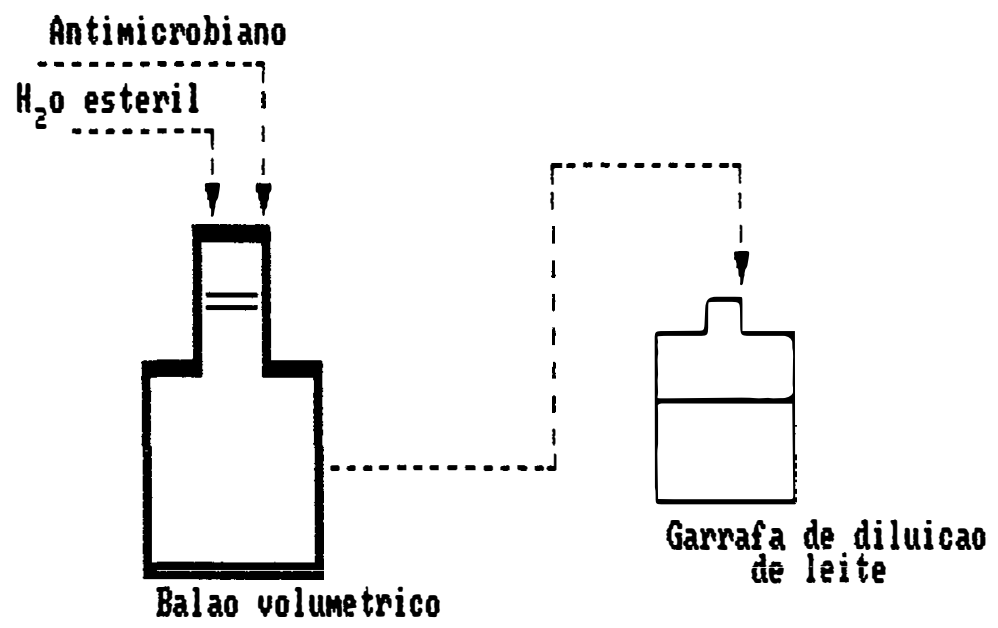

Figura 2 - Preparo do antimicrobiano 


\subsubsection{Preparo do inóculo}

As culturas congeladas em "LITMUS MILK" foram colocadas em estufa a $35 \pm 1^{\circ} \mathrm{C}$ por \pm 36 horas. A partir disto foram tranferidas com auxílio de alça de platina para tubos contendo $5 \mathrm{ml}$ de meio de cultivo e incubados por \pm 18 horas a $35 \pm 1{ }^{\circ} \mathrm{C}$.

\subsubsection{Concentracão Inibitória Mínima (C.I.M)}

o termo Concentração Inibitória Mínima diz respeito a menor dose requerida para inibir o crescimento de um microrganismo. Neste trabalho utilizou-se dois diferentes parâmetros para a determinação desta dose:

\subsubsection{Concentracão Inibitória Mínima em meio} sólido (C.I.M.S)

3.2.4.1.1. Preparo das Placas - O meio foi preparado, e $20 \mathrm{ml}$ foram transferidos para tubos de cultura e esterilizados em autoclave a $121^{\circ} \mathrm{C}$ por 15 minutos - Os tubos foram então mantidos em Banho Maria com temperatura controlada até atingirem temperatura entre 45 e $48^{\circ} \mathrm{C}$. Quando estes atingiam a temperatura mencionada os antimicrobianos eram adicionados aos mesmos nas dosagens desejadas e homogenizados em agitador tipo "VORTEX" e então transferidos para placas estéreis. Essas placas foram preparadas com \pm 24 horas de antecedência e armazenadas a temperatura ambiente dentro da camara asséptica para que estas estivessem desidratadas, e não ocorresse união dos diferentes inóculos em função de alta umidade dentro das 
placas.

Outro cuidado que se tomou foi de não se utilizar as placas preparadas com mais de 24 horas, uma vez que o "poder" do antimicrobiano pode ficar comprometido em função do tempo de armazenamento destas.

\subsection{Inoculacão - Utilizou-se} para a inoculação o aplicador preconizado por STERRS et al. (1959),o qual consiste em uma placa de aço inox com $8 \mathrm{~cm} \mathrm{x}$ $4.5 \mathrm{~cm} \times 1 \mathrm{~cm}$ a qual contém 12 orifícios com $1 \mathrm{~cm}$ de diâmetro e $0.5 \mathrm{~cm}$ de profundidade cada um. Consiste ainda de uma tampa com 12 hastes, as quais são os instrumentos da inoculação (Figura 3). Das culturas previamente preparadas como descrito em 2.3. foram tranferidos $200 u l$ de cada uma das oito bactérias para 8 dos 12 orifícios do aplicador esterilizado. Utilizou-se apenas 8 orifícios devido ao fato de ter se trabalhado com bactérias do gênero Bacillus, o qual apresenta espalhamento na placa quando se desenvolve podendo assim comprometer a leitura final. Os orificios desprezados foram os 4 centrais.

A inoculação foi feita partindo-se do CONTROLE para as concentrações maiores, tendo em vista que não é raro - transporte de um pouco de meio nas hastes de inoculação, evitando-se deste modo interferência nos resultados.

As placas inoculadas ficaram a temperatura ambiente por 1 hora antes serem incubadas para que o inóculo difundisse no meio de cultivo. 
A partir disto as placas foram incubadas a $35^{\circ} \mathrm{C} \pm 1.0$ por 18 horas ou até o crescimento do CONTROLE.

3.2.4.1.3. Leitura - As leituras das placas com os antimicrobianos foram feitas tomando por base - crescimento das bactérias da placa CONTROLE (Figura 4). Foram feitas cinco repetições para cada um dos antimicrobianos em associação com as bactéfias testadas. O esquema do teste se encontra na Figura 5. 3.2.4.2. Concentracão Inibitória Mínima em meio liquido (C.I.M.L)

3.2.4.2.1. Preparo dos tubos - 0 meio foi preparado, e $5 \mathrm{ml}$ foram transferidos para tubos de cultura e esterilizados em autoclave a $121^{\circ} \mathrm{C}$ por 15 minutos. Os antimicrobianos foram dosados e os tubos homogenizados em agitador tipo "VORTEX".

3.2.4.2.2. Inoculacão - A inoculação foi feita a partir das culturas crescidas como descrito em 2.3. Foram inoculados $15 u l$ de cada cultura para cada um dos tubos.

Os tubos foram incubados a $35^{\circ} \mathrm{C} \pm 1.0$ por 18 horas ou até o crescimento do CONTROLE.

3.2.4.2.3. Leitura - A leitura foi feita a partir do crescimento do CONTROLE. Quando este apresentava sinais de crescimento (turvação) os outros tubos eram lidos.

Foram feitas 3 repetições para cada um do 
antimicrobianos.

o esquema completo deste teste se encontra na Figura 6 .

\subsubsection{Concentração Bactericida Mínima (C.B.M)}

o termo Concentração Bactericida Mínima diz respeito à menor dose requerida para matar toda a população de microrganismo quando em contato com o antimicrobiano. Isto é constatado a partir do momento que o microrganismo é retirado do contato com o agente inibidor e tranferido para um meio de cultivo livre deste produto, e este não consegue se desenvolver.

3.2.5.1. Preparo dos tubos: 0 meio foi preparado e $5 \mathrm{ml}$ foram distribuidos em tubos cultura e esterilizados em autoclave a $121^{\circ} \mathrm{C}$ por 15 minutos.

3.2.5.2. Inoculação: Os tubos foram inoculados a partir dos tubos provenientes do teste de C.I.M. em meio líquido com auxílio de palitos de madeira esteréis.

Os tubos selecionados foram aqueles que não apresentaram sinais de crescimento, isto é, aqueles em que os microrganismos ficaram inibidos ou foram destruidos quando em presença do antimicrobiano.

Quando os microrganismos foram transferidos para o meio de cultivo sem $\circ$ agente antimicrobiano proporcionou-se condiçōes para que estes, se inibidos, 
crescessem.

Os tubos foram então incubados a $35^{\circ} \mathrm{C} \pm 1.0$

por 48 horas. Este tempo foi dado para que o microrganismo se inibido, tivesse tempo de se recuperar dos danos causados pelo antimicroblano.

Foram feitas 3 repetiçōes para cada um dos antimicrobianos.

O esquema completo deste teste se encontra na Figura 7 . 


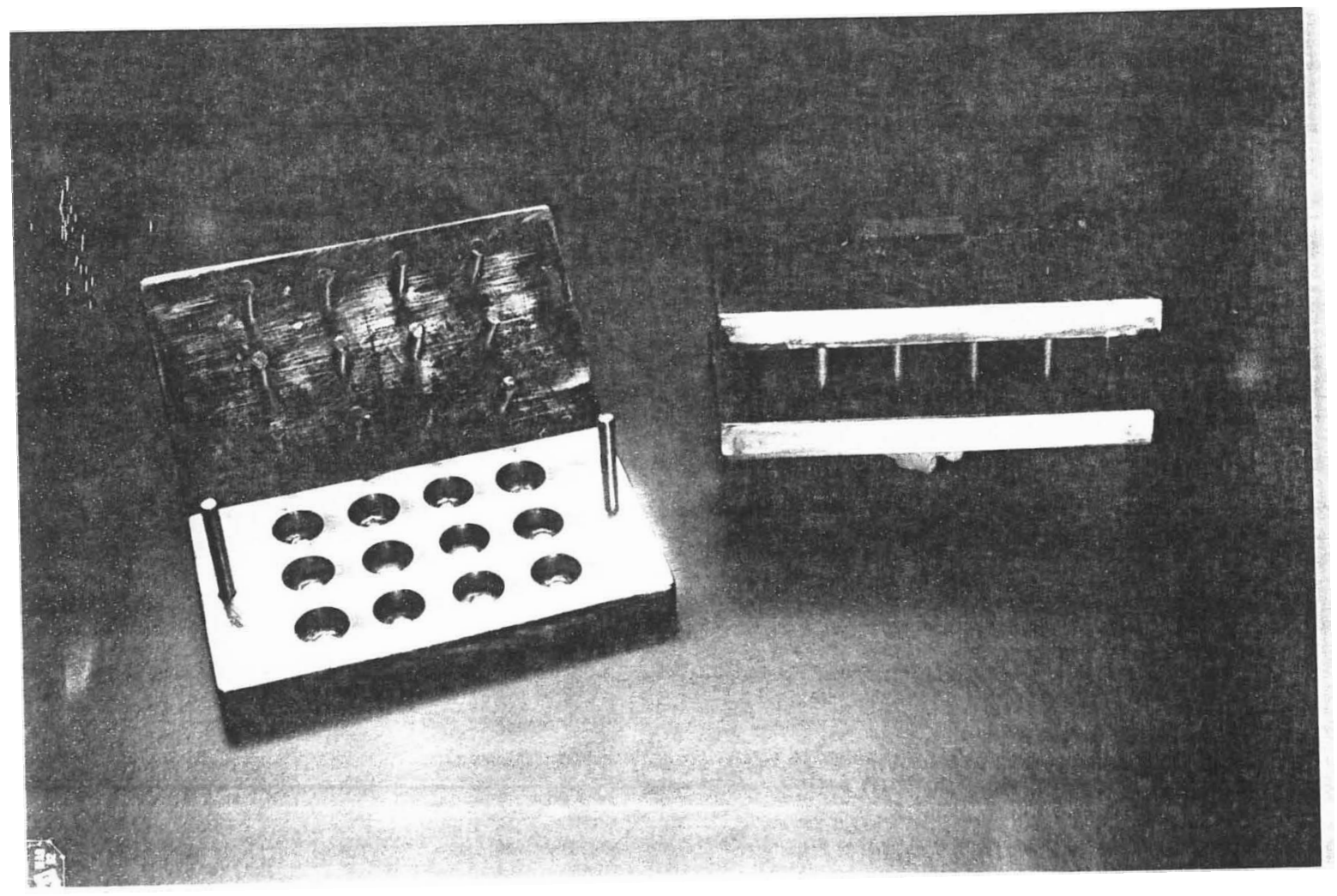

Figurā 3 - Aplicador preconizado por STERRS et al. (1959). 


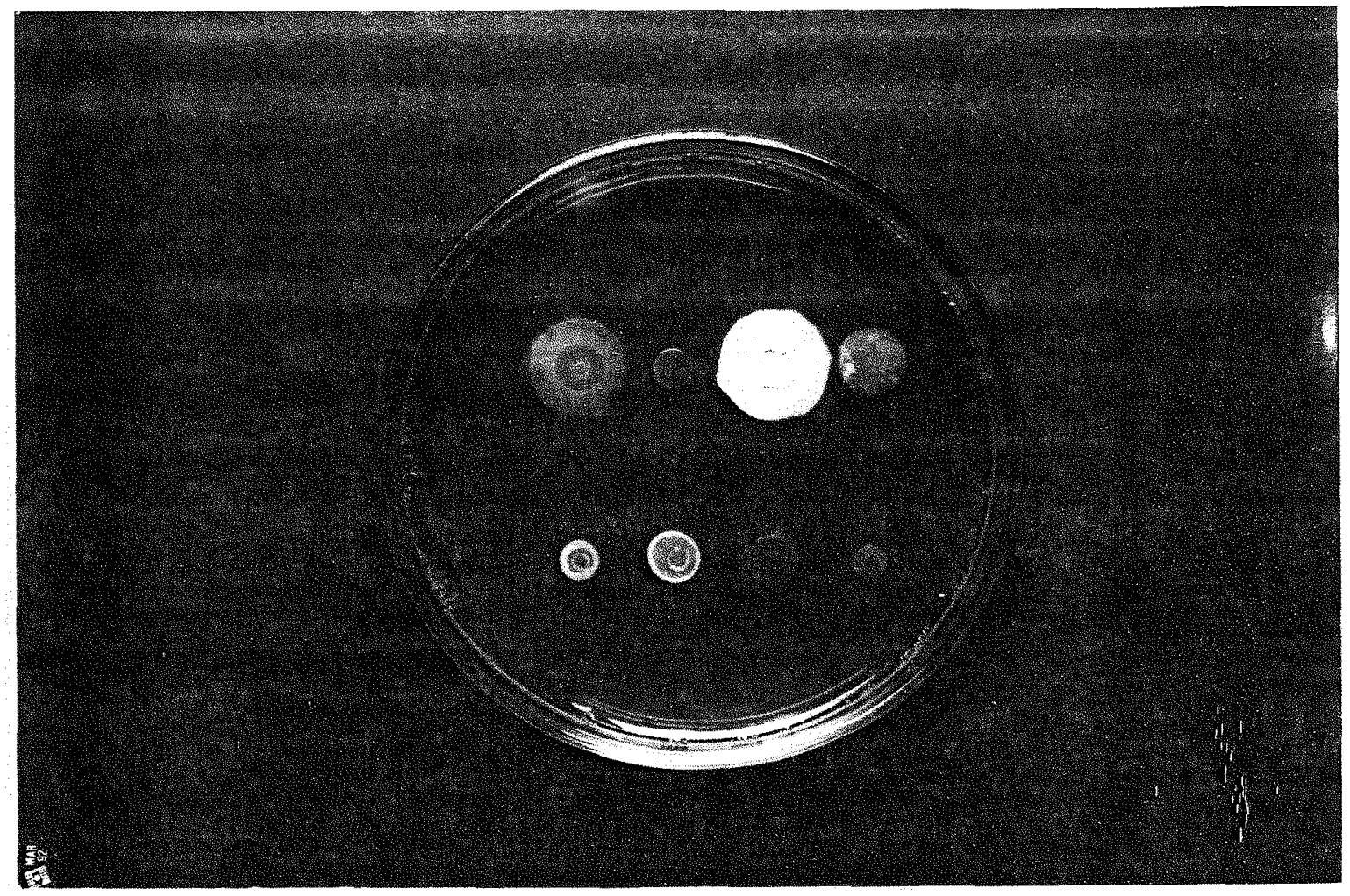

\begin{tabular}{llll|}
\hline 1 & 2 & 3 & 4 \\
5 & 6 & 7 & 8 \\
\hline
\end{tabular}

1. B. subtilis

2. B. brevis

3. B. megaterium

4. B. coagulans

5. L. mesenteroides

6. L. plantarum

7. L. fermentum

8. L. buchneri

Figura 4 - Crescimento das bactérias da placa controle (18 horas de incubação) 


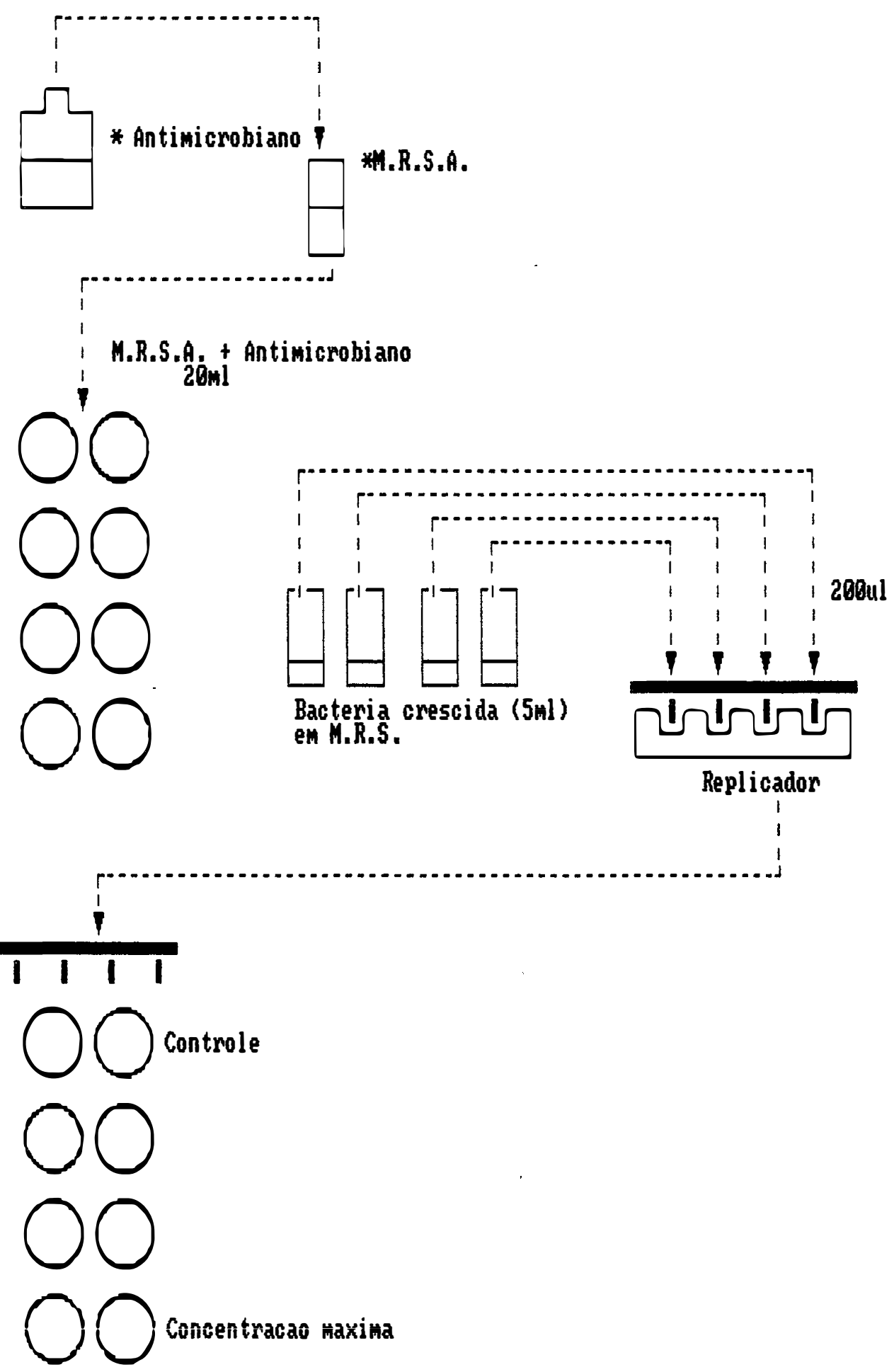

Figura 5 - Concentração Inibitória Mínima em meio sólido. 


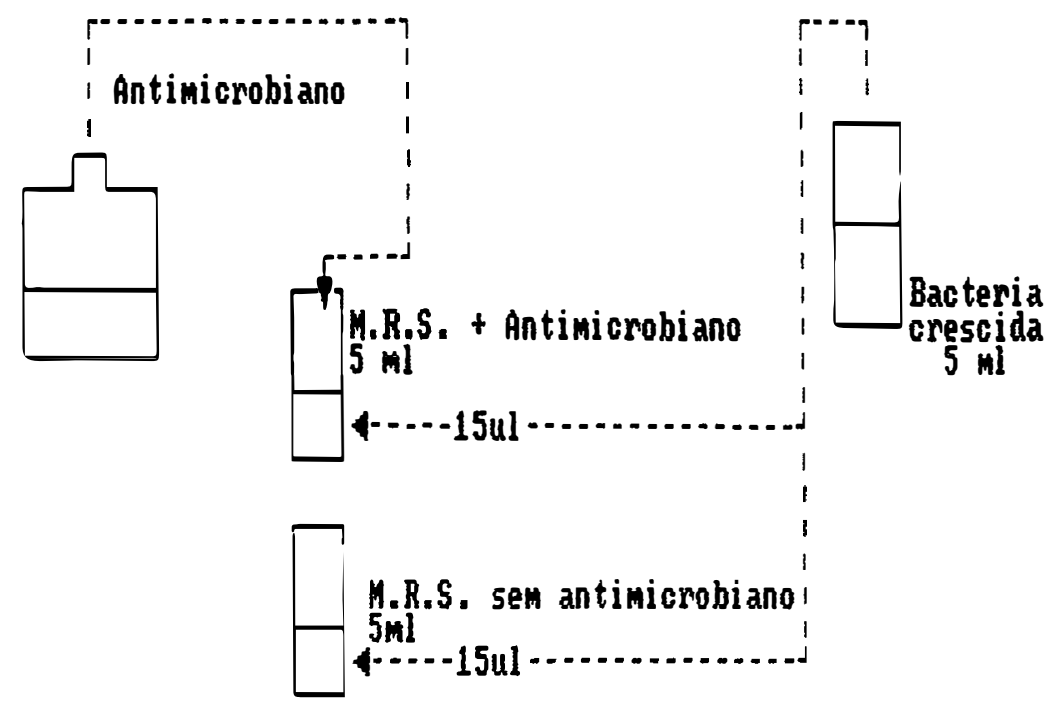

Figura 6 - Concentração Inibitória Mínima em meio líquido.

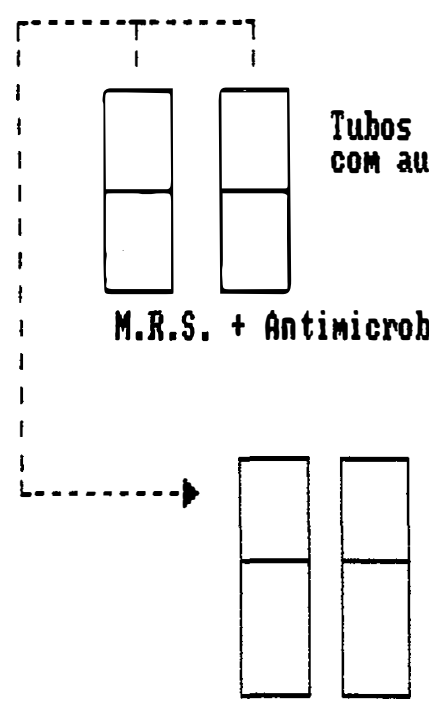

M.R.S. Sew Antimicrobiano $5 \mathrm{ml}$

Figura 7 - Concentração Bactericida Mínima. 


\section{RESULTADO E DISCUSSÃO}

\subsection{METODOLOGIA PARA AVALIAÇÃO DE C.I.M}

Neste trabalho, quarenta testes envolvendo cinco antimicrobianos e oito microrganismos foram realizados utilizando os parâmetros C.I.M.L e C.I.M.S. Em seis das combinações experimentadas diferenças entre os dois parâmetros foram observadas. Essas diferenças foram também encontradas por KENNY et al. (1989), que trabalhando com bactérias Gram positivas de interesse clínico constataram que 13.98 dos resultados mostravam um valor de C.I.M.L maiores e 25.48 destes valores se mostraram menores quando comparados com C.I.M.S.

BRASS et al. (1979), trabalhando com dez linhagens de leveduras associadas a três diferentes antimicrobianos obtiveram valores de C.I.M.L e C.I.M.S diferentes e atribuiram estas diferenças ao modo de ação das drogas testadas.

OLIVEIRA et al. (1987), propuseram testes para avaliar a faixa de inibição das bactérias de interesse para - setor sucroalcooleiro quando frente a antimicrobianos, tanto em meio liquido trabalhando com um "coquetel" de bactérias como em meio sólido utilizando culturas puras, sem 
entretanto fazer comparações entre as duas metodologias.

Pelos resultados obtidos neste trabalho, podese sugerir que as causas dessas diferenças, não estejam associadas somente ao modo de ação dos antimicrobianos, mas também ao microrganismo utilizado. Nos seis casos onde os valores de C.I.M.L e C.I.M.S diferiram, quatro estão relacionados ao antibiótico fermacol em associação com Lactobacillus buchneri, L. fermentum, Leuconostoc mesenteroides e B. brevis. Os outros dois casos que mostraram diferença estão associados ao Bacillus subtilis com os produtos virginiamicina e cloranfenicol.

No caso do fermacol, se somente o modo de ação do antimicrobiano fosse responsável pela diferença entre os valores de C.I.M.L e C.I.M.S ter-se-ia estas para todos os microrganismos, o que não ocorreu. Isso indica que o fermacol atua de forma diferente em meio sólido e líquido para alguns microrganismos mas não para outros. Da mesma forma, se somente $\circ$ microrganismo fosse responsável pelas diferenças dos valores encontrados dever-se-ia obter valores diferentes para as associações do $B$. subtilis com os produtos fermacol, penicilina e quaternário de amônia.

A Tabela 2 mostra os resultados obtidos para os dois parâmetros testados, e o que se observa é que em todos os seis casos que mostraram diferenças nos resultados, concentrações menores foram obtidas para C.I.M.L.

Este fato indica que a ação do agente 
antimicrobiano fica prejudicada, quando em meio sólido, uma vez que, em meios contendo agar $\circ$ contato microrganismo/produto diminue quando comparado ao microrganismo cultivado em meio líquido. Entretanto as associações estudadas neste trabalho são pequenas quando comparadas a diversidade da flora existente no processo de produção de álcool e dos agentes antimicrobianos utilizados neste. Em função disto, da inexistência de trabalhos similares para este setor na literatura e do pequeno número (6) de casos que apresentaram diferenças entre os dois parâmetros, acredita-se por hora que qualquer um destes mostra-se adequado para a avaliação de agentes antimicrobianos.

Por outro lado, quando se comparam os dois parâmetros, a C.I.M.S tem uma grande vantagem sobre a C.I.M.L no que diz respeito as condições de adequação do teste para - setor sucroalcooleiro, uma vez que a primeira metodologia pode testar até 12 bactérias por placa contra apenas uma bactéria por tubo da C.I.M.L. Desta forma permite-se que um maior número de bactérias seja testado, assim como os produtos disponíveis no mercado em um menor período de tempo. Isto facilita a decisão quando se faz necessário a aplicação de um dado produto.

Outros aspectos que contribuem para a utilização desta metodologia seriam: a fácil deteç̧ão de contaminação do teste pela facilidade em se distinguir 
contaminante crescendo na placa, e por se tratar de testes mais baratos que os realizados em meio líquido. Para se testar 12 bactérias em tubo se utilizam-se $60 \mathrm{ml}$ de meio de cultivo contra $20 \mathrm{ml}$ utilizados na placa.

A desvantagem deste parâmetro (C.I.M.S) é que a partir deste não é possível se determinar a C.B.M, o que não ocorre quando se utiliza o parâmetro da C.I.M.L.

Todavia, é discutivel a utilização dos antimicrobianos em doses letais (C.B.M), uma vez que estas são, de um modo geral, muito maiores que a C.I.M como mostram os resultados contidos na Tabela 2 e que, na maioria das vezes, estas doses letais não foram detectadas mesmo utilizando-se dosagens dezesseis vezes maiores que a recomendada, o que tornaria a aplicação de um dado produto economicamente inviável. 


\subsection{AÇÃO DOS ANTIMICROBIANOS SOBRE AS BACTERIAS}

\subsubsection{Lactobacillus buchneri}

A Figura 8 e a Tabela 2 mostram a ação de todos os antimicrobianos sobre $L$. buchneri. Para que este microrganismo seja inibido são necessárias dosagens de: 8 ppm de cloranfenicol, 1-2 ppm de fermacol, $0.5 \mathrm{ppm}$ de penicilina, 10 ppm de quaternário de amônia e 0.25 ppm de virginiamicina. No que se refere a dose letal (C.B.M) para este microrganismo são requeridos: $8 \mathrm{ppm}$ de penicilina, 40 ppm de quaternário de amônio e 0.5 ppm de virginiamicina. Para os outro produtos testados (cloranfenicol e fermacol) não foi possivel determinar a C.B.M com a maior dose testada (16 ppm). 
Tabela 2 : Concentração Inibitória Mínima (C.I.M) em meio líquido (C.I.M.L) e sólido (C.I.M.S) e Concentração Bactericida Minima (C.B.M) para todas as bactérias estudadas frente aos antimicrobianos: CL - cloranfenicol, FM fermacol, PC - penicilina, QA - quaternário de amônio e VM virginiamicina.

\begin{tabular}{|c|c|c|c|c|c|c|}
\hline & & $C L$ & \multicolumn{3}{|c|}{ CONCENTRAÇÃO (PPM) } & VM \\
\hline L. buchneri & $\begin{array}{l}C \cdot I \cdot M \cdot S \\
C \cdot I \cdot M \cdot L \\
C \cdot B \cdot M\end{array}$ & $\begin{array}{l}8 \\
8 \\
\text { N.D }\end{array}$ & $\begin{array}{l}2 \\
1 \\
N . D\end{array}$ & $\begin{array}{l}0.5 \\
0.5 \\
8\end{array}$ & $\begin{array}{l}10 \\
10 \\
40\end{array}$ & $\begin{array}{l}0.25 \\
0.25 \\
0.5\end{array}$ \\
\hline L. fermentum & $\begin{array}{l}C \cdot I \cdot M \cdot S \\
C \cdot I \cdot M \cdot L \\
C \cdot B \cdot M\end{array}$ & $\begin{array}{l}N . D \\
N . D \\
N . D\end{array}$ & $\begin{array}{l}2 \\
1 \\
\text { N.D }\end{array}$ & $\begin{array}{l}0.5 \\
0.5 \\
\text { N.D }\end{array}$ & $\begin{array}{c}10 \\
10 \\
40\end{array}$ & $\begin{array}{c}0.25 \\
0.25 \\
\text { N.D }\end{array}$ \\
\hline L. plantarum & $\begin{array}{l}C \cdot I \cdot M \cdot S \\
C \cdot I \cdot M \cdot L \\
C \cdot B \cdot M\end{array}$ & $\begin{array}{l}N . D \\
N . D \\
N . D\end{array}$ & $\begin{array}{l}N . D \\
N . D \\
N . D\end{array}$ & $\begin{array}{l}N . D \\
N . D \\
N . D\end{array}$ & $\begin{array}{l}10 \\
10 \\
80\end{array}$ & $\begin{array}{l}N \cdot D \\
N \cdot D \\
N \cdot D\end{array}$ \\
\hline L. mesenter. & $\begin{array}{l}C \cdot I \cdot M \cdot S \\
C \cdot I \cdot M \cdot L \\
C \cdot B \cdot M\end{array}$ & $\begin{array}{l}N . D \\
N . D \\
N . D\end{array}$ & $\begin{array}{l}2 \\
1 \\
N . D\end{array}$ & $\begin{array}{l}0.5 \\
0.5 \\
N . D\end{array}$ & $\begin{array}{c}10 \\
10 \\
80\end{array}$ & $\begin{array}{l}0.25 \\
0.25 \\
\text { N.D }\end{array}$ \\
\hline B. brevis & $\begin{array}{l}\text { C.I.M.S } \\
\text { C.I.M.L } \\
\text { C.B.M }\end{array}$ & $\begin{array}{l}N . D \\
N . D \\
N . D\end{array}$ & $\begin{array}{l}2 \\
1 \\
N . D\end{array}$ & $\begin{array}{l}0.5 \\
0.5 \\
8\end{array}$ & $\begin{array}{c}10 \\
10 \\
40\end{array}$ & $\begin{array}{l}0.25 \\
0.25 \\
16\end{array}$ \\
\hline B. megaterium & $\begin{array}{l}C \cdot I \cdot M \cdot S \\
C \cdot I \cdot M \cdot L \\
C \cdot B \cdot M\end{array}$ & $\begin{array}{l}4 \\
4 \\
\text { N.D }\end{array}$ & $\begin{array}{l}0.25 \\
0.25 \\
4\end{array}$ & $\begin{array}{l}0.5 \\
0.5 \\
N . D\end{array}$ & $\begin{array}{c}10 \\
10 \\
40\end{array}$ & $\begin{array}{l}0.25 \\
0.25 \\
2\end{array}$ \\
\hline B. coagulans & $\begin{array}{l}C \cdot I \cdot M \cdot S \\
C \cdot I \cdot M \cdot L \\
C \cdot B \cdot M\end{array}$ & $\begin{array}{l}4 \\
4 \\
\text { N.D }\end{array}$ & $\begin{array}{l}0.25 \\
0.25 \\
4\end{array}$ & $\begin{array}{l}N \cdot D \\
N \cdot D \\
N \cdot D\end{array}$ & $\begin{array}{l}10 \\
10 \\
40\end{array}$ & $\begin{array}{l}0.5 \\
0.5 \\
2\end{array}$ \\
\hline B. subtilis & $\begin{array}{l}C \cdot I \cdot M \cdot S \\
C \cdot I \cdot M \cdot L \\
C \cdot B \cdot M\end{array}$ & $\begin{array}{l}4 \\
2 \\
\text { N.D }\end{array}$ & $\begin{array}{l}0.25 \\
0.25 \\
2\end{array}$ & $\begin{array}{l}2 \\
2 \\
N . D\end{array}$ & $\begin{array}{l}10 \\
10 \\
40\end{array}$ & $\begin{array}{l}1 \\
0.5 \\
2\end{array}$ \\
\hline
\end{tabular}

N.D. Não detectado 


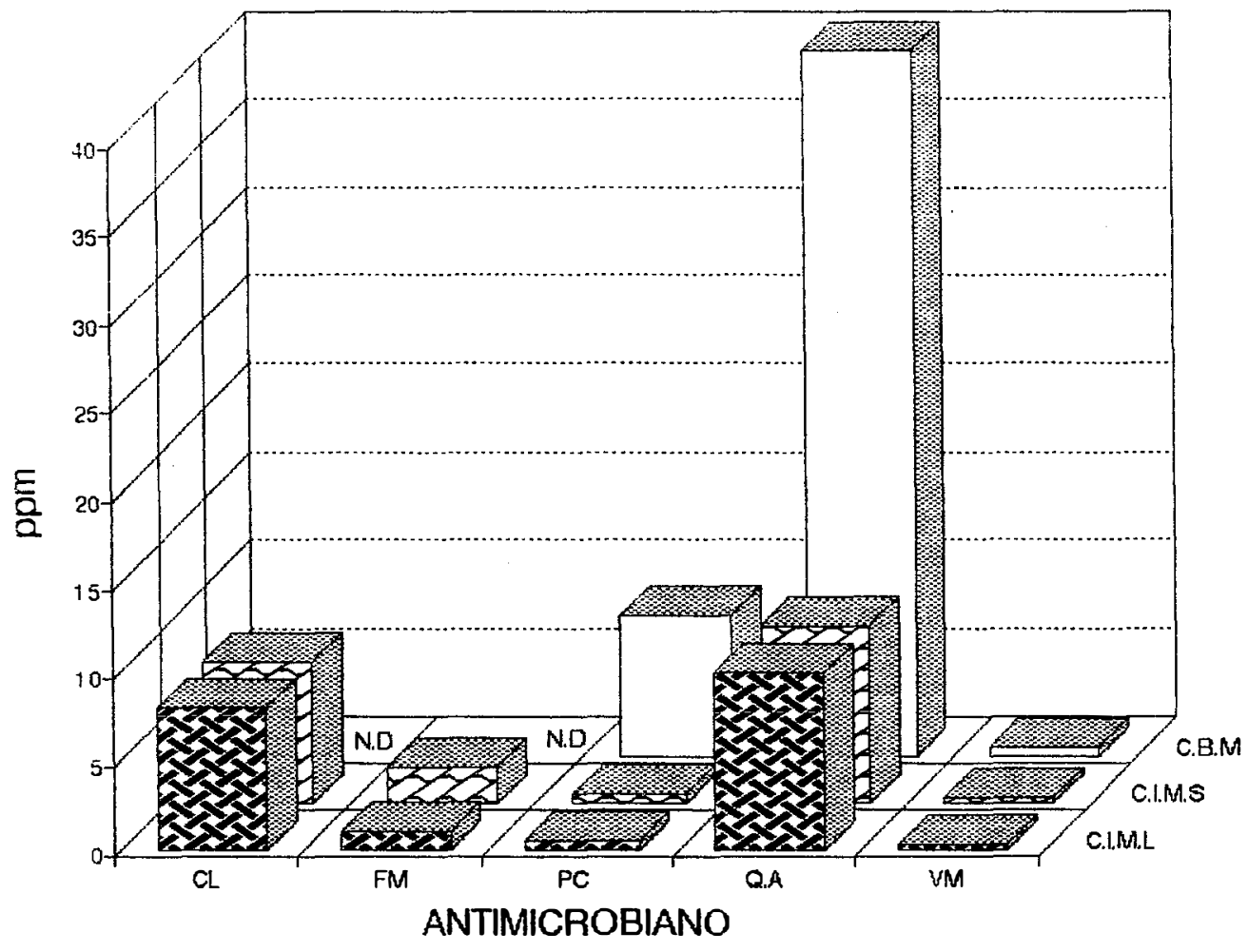

Figura 8 - Acão dos antimicrobianos testados sobre $L$. buchneri quanto à: C.I.M.L, C.I.M.S e C.B.M onde CL cloranfenicol, FM - fermacol, PC - penicilina, Q.A quaternário de amônio, VM - virginiamicina e N.D - não detectado. 


\subsubsection{Lactobacillus fermentum}

A Figura 9 e a Tabela 2 mostram a ação de todos os antimicrobianos sobre L. fermentum.

Para que este microrganismo seja inibido são necessárias dosagens de: $1-2 \mathrm{ppm}$ de fermacol, $0.5 \mathrm{ppm}$ de penicilina, 10 ppm de quaternário de amônio, 0.25 ppm de virginiamicina. Para cloranfenicol este microrganismo resistiu até a maior dose testada (16ppm).

No que diz respeito a C.B.M apenas quarternário de amônio foi eficiente entre os antimicrobianos testados. Foram necessários $40 \mathrm{ppm}$ para que isto ocorresse.

Em relação aos outros produtos testados a dose máxima utilizada foi de $16 \mathrm{ppm}$, a qual não se mostrou como letal para este microrganismo.

BOONSONG \& DAENGSUBA (1985), avaliando a ação de 3 diferentes marcas comerciais de quaternário de amônio sobre este microrganismo afirmam que este é inibido na faixa que varia de 10 a 20 ppm o que coincide com os dados deste trabalho (10 ppm).

Segundo PRINCIPAIS bactérias contaminantes da fermentação alcoólica, suas características e sensibilidade a antihińticns (1991), essa bactéria quando colocada em contato com virginiamicina, penicilina e fermacol em uma concentração de $1 \mathrm{ppm}$ por três horas foi reduzida ao nível de 
42.7웅 e 15용 respectivamente para os dois primeiros produtos e não ocorreu redução para o fermacol. Quando esta bactéria foi deixada em contato por seis horas com os produtos as reduções foram de 46,20 e 14 웅 respectivamente para virginiamicina, penicilina e fermacol.

o controle efetivo deste microrganismo nos processos fermentativos é de grande importância uma vez que trabalhos feitos por YOKOYA (1989), e YOKOYA \& OLIVA-NETO (1991), associam a presença de algumas linhagens deste microrganismo a problemas de floculação. 


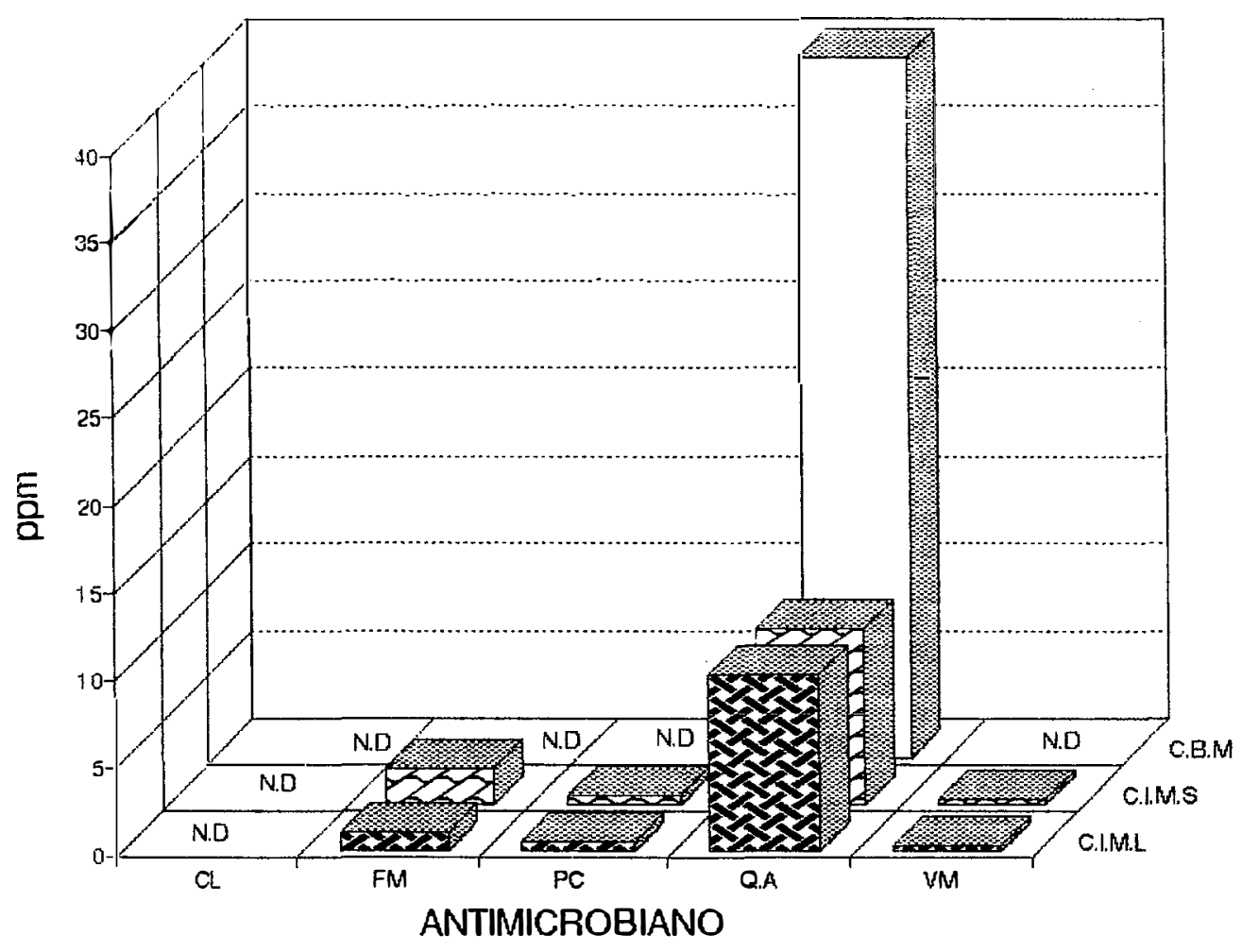

Figura 9 - Acão dos antimicrobianos testados sobre $L$. fermentum quanto à: C.I.M.L, C.I.M.S. e C.B.M. onde CL cloranfenicol, FM - fermacol, PC - penicilina, Q.A

- quaternário de amônio, VM - virginiamicina e ND - não detectado. 


\subsubsection{Lactobacillus plantarum}

A Figura 10 e a Tabela 2 mostram a ação de todos os antimicrobianos sobre L. plantarum.

Para que este microrganismo seja inibido é requerido uma dosagem de 10 ppm de quaternário de amônio, enquanto que os outros antimicrobianos testados não tiveram nenhuma ação sobre esta bactéria mesmo frente às maiores doses testadas (16 ppm).

Em relação a C.B.M, apenas quaternário de amônia em uma dosagem de 80 ppm foi eficiente.

Segundo PRINCIPAIS bactérias contaminantes da fermentação alcoólica, suas características e sensibilidade a antibióticos (1991), essa bactéria quando colocada em contato com virginiamicina, penicilina e fermacol em uma concentração de 1 ppm por três horas, sua população sofreu redução ao nível de 72.9 e 28 o respectivamente para virginiamicina e penicilina e para fermacol não houve redução na população. Quando o tempo de contato aumentou para seis horas os índices de redução foram de $85.9,40$ e 26.308 para virginiamicina, penicilina e fermacol respectivamente. 


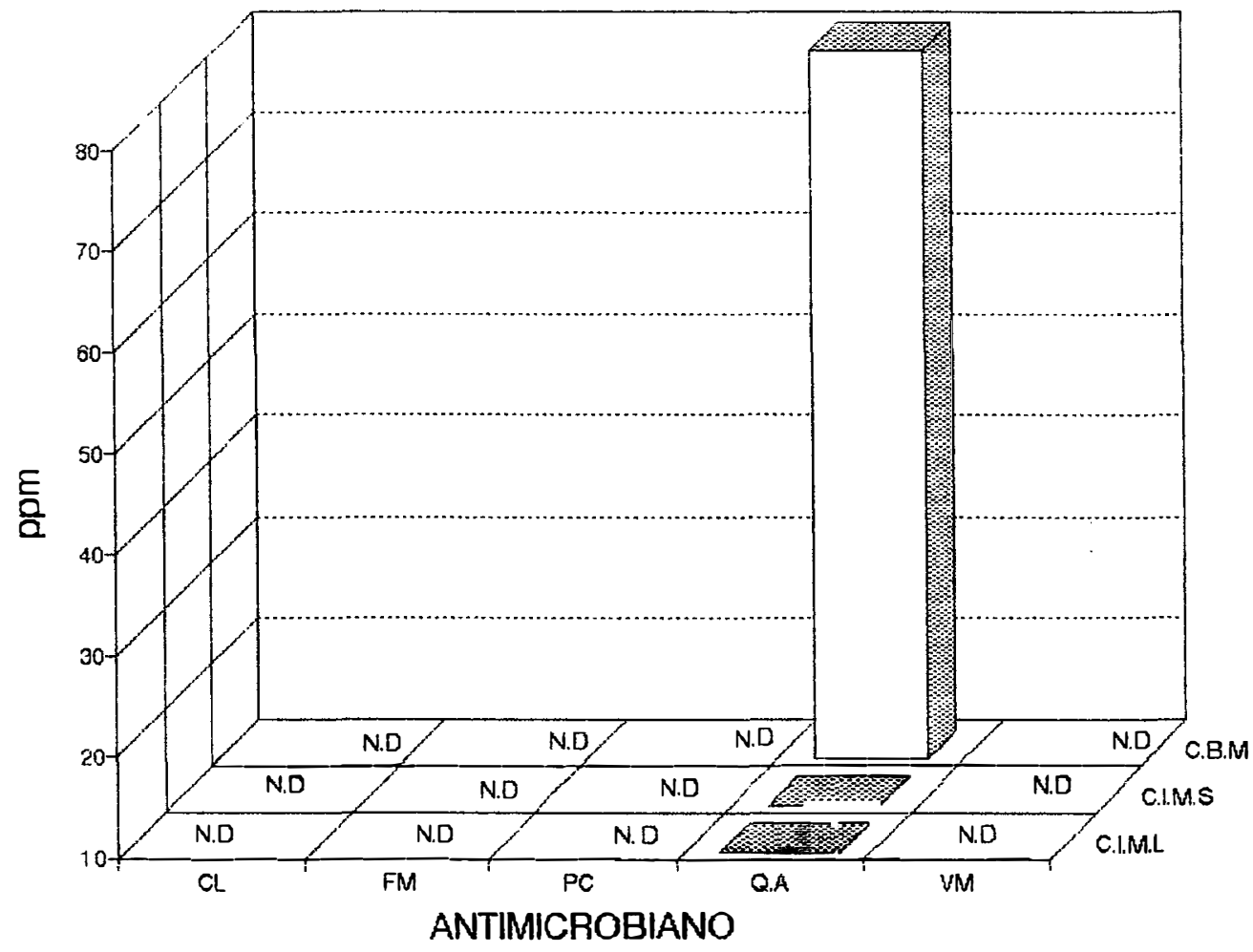

Figura 10 - Acão dos antimicrobianos testados sobre $L$. plantarum quanto à: C.I.M.L, C.I.M.S e C.B.M onde CL cloranfenicol, FM - fermacol, PC - penicilina, Q.A quaternário de amônio, VM - virginiamicina e ND - não detectado. 


\subsubsection{Leuconostoc mesenteroides}

A figura 11 e a Tabela 2 mostram a ação dos antimicrobianos sobre L. mesenteroides.

Para a inibição desta bactéria foram necessários: 1-2 ppm de fermacol, $0.5 \mathrm{ppm}$ de penicilina, 10 ppm de quaternário de amônio e 0.25 de virginiamicina. Para - produto cloranfenicol 16 ppm não foram suficientes para inibir este microrganismo.

No que se refere a C.B.M apenas quaternário de amônio na dosagem de $80 \mathrm{ppm}$ foi eficiente para promover este fenômeno, sendo que os outros produtos não $\circ$ fizeram até a concentração de $16 \mathrm{ppm}$.

Muitos trabalhos foram feitos para determinação da dosagem necessária para eliminar este microrganismo dos processos fermentativos. CEREDA et al. (1981), trabalhando com diferentes produtos, sem no entanto mencionarem o princípio ativo, encontraram dosagens que variam de 8 a $20 \mathrm{ppm}$ para que Leuconostoc sp fosse inibido e valores maiores de $20 \mathrm{ppm}$ para ação bactericida neste microrganismo.

BOONSONG \& WIWUT (1985), estudaram a ação de 3 produtos que tinham como princípio ativo o quaternário de amônio e concluiram que em doses variando entre 10 e 20 ppm este microrganismo fica inibido. OLIVEIRA et al. (1987), encontrou valores de 50 ppm (quaternário de amônio com 48.98 de princípio ativo) e 75 ppm (quaternário de amônio com 
$50.75 \%$ de princípio ativo) para que a inibição do Leuconostoc Rec fosse promovida. ROSALES (1989), descreve que células de Leuconostoc mesenteroides subsp. mesenteroides quando colocadas em contato por 180 minutos com penicilina na concentração de $30 \mathrm{ppm}$ são afetadas pelo produto reduzindo a população em 98.7\%, enquanto que a mesma dosagem de quaternário de amônio mostrou queda de $73.8 \%$ no número de células do microrganismo.

RODINI (1989), estudou a ação de penicilina sobre duas linhagens de Leuconstoc sp e verificou que este microrganismo cresce em concentrações de até $300 \mathrm{ppm}$.

Segundo PRINCIPAIS bactérias contaminantes da fermentação alcoólica, suas características e sensibilidade a antibióticos (1991), essa bactéria quando colocada em contato com virginiamicina, penicilina e fermacol em uma concentração de 1 ppm por três horas é reduzida ao nível de $90.5,91.30$ e $89.5 \%$ respectivamente. Quando $\circ$ tempo de contato aumentou para 6 horas os índices de redução aumentaram respectivamente para 99.5, 99.20 e 99.10\%. 


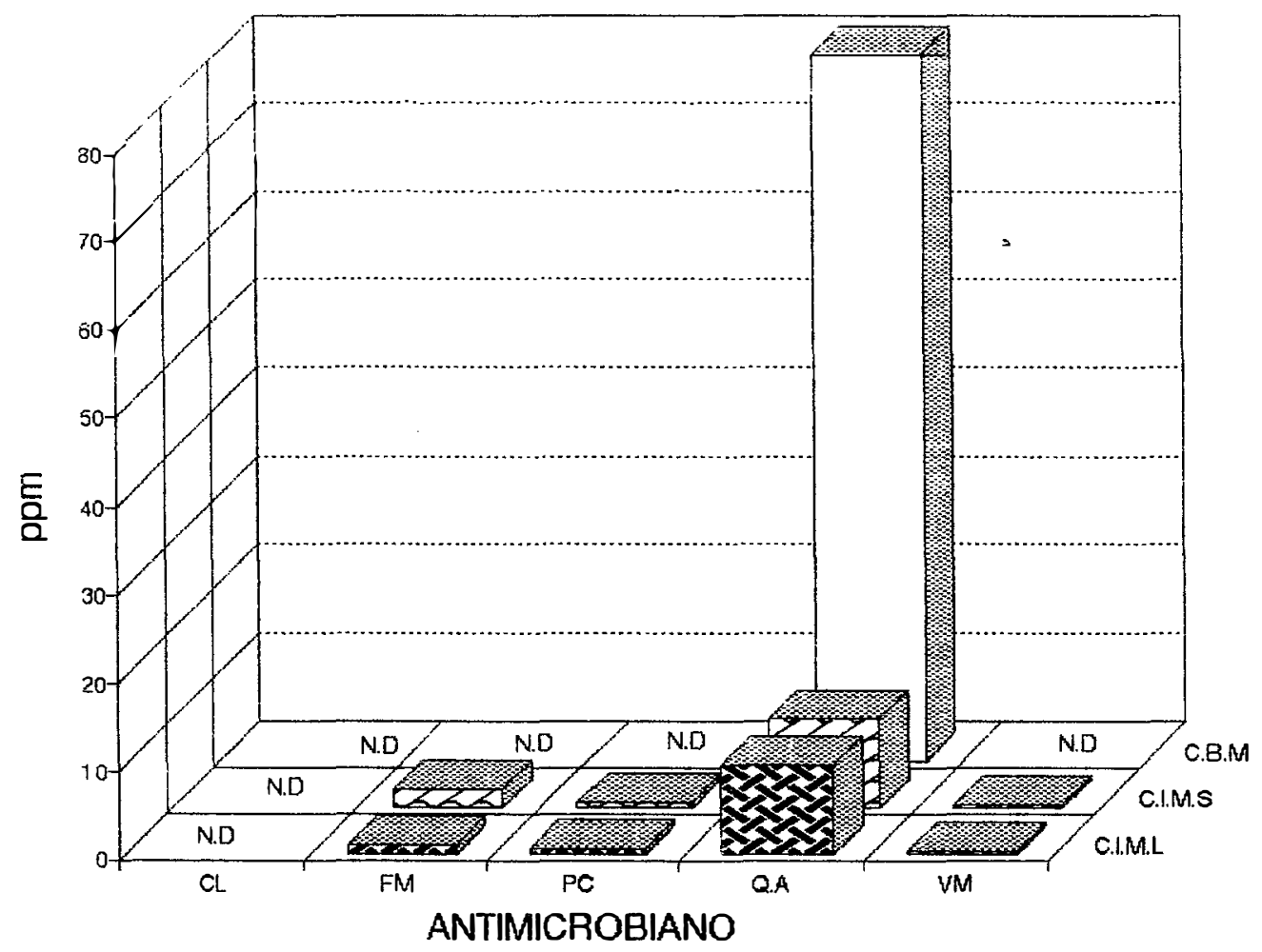

Figura 11 - Acão dos antimicrobianos testados sobre $L$. mesenteroides quanto a: C.I.M.L, C.I.M.S e C.B.M onde CL cloranfenicol, FM - fermacol, PC - penicilina, Q.A quaternario de amônio, VM - virginiamicina e ND não detectado. 


\subsubsection{Bacillus brevis}

A Figura 12 e a Tabela 2 mostram a ação de todos os antimicrobianos para $B$. brevis.

Para a inibição deste microrganismo foram necessários: $1-2 \mathrm{ppm}$ de fermacol, $0.5 \mathrm{ppm}$ de penicilina, 10 ppm de quaternário de amônio e $0.25 \mathrm{ppm}$ de virginiamicina. Em relação a cloranfenicol, com 16 ppm este microrganismo ainda apresentou sinais de crescimento. Para se atingir a C.B.M são requeridos: $8 \mathrm{ppm}$ de penicilina, $40 \mathrm{ppm}$ de quaternário de amônio e 16 ppm de virginiamıcina. Quanto ao cloranfenicol e fermacol as maiores dosagens utilizadas (16 ppm) não conseguiram ser letais para este microrganismo.

Segundo PRINCIPAIS bactérias contaminantes da fermentação alcoólica, suas caracteristicas e sensibilidade a antibióticos (1991), uma população desta bactéria quando colocada em contato com virginiamicina, penicilina e fermacol em uma concentração de 1 ppm por três horas é reduzida ao nível de 19.4욤 para penicilina, sendo que para os outros dois produtos testados diferenças significativas não foram observadas. Quando o tempo de contato aumentou para 6 horas reduções significativas não foram observadas para virginiamicina, penicilina e fermacol. 


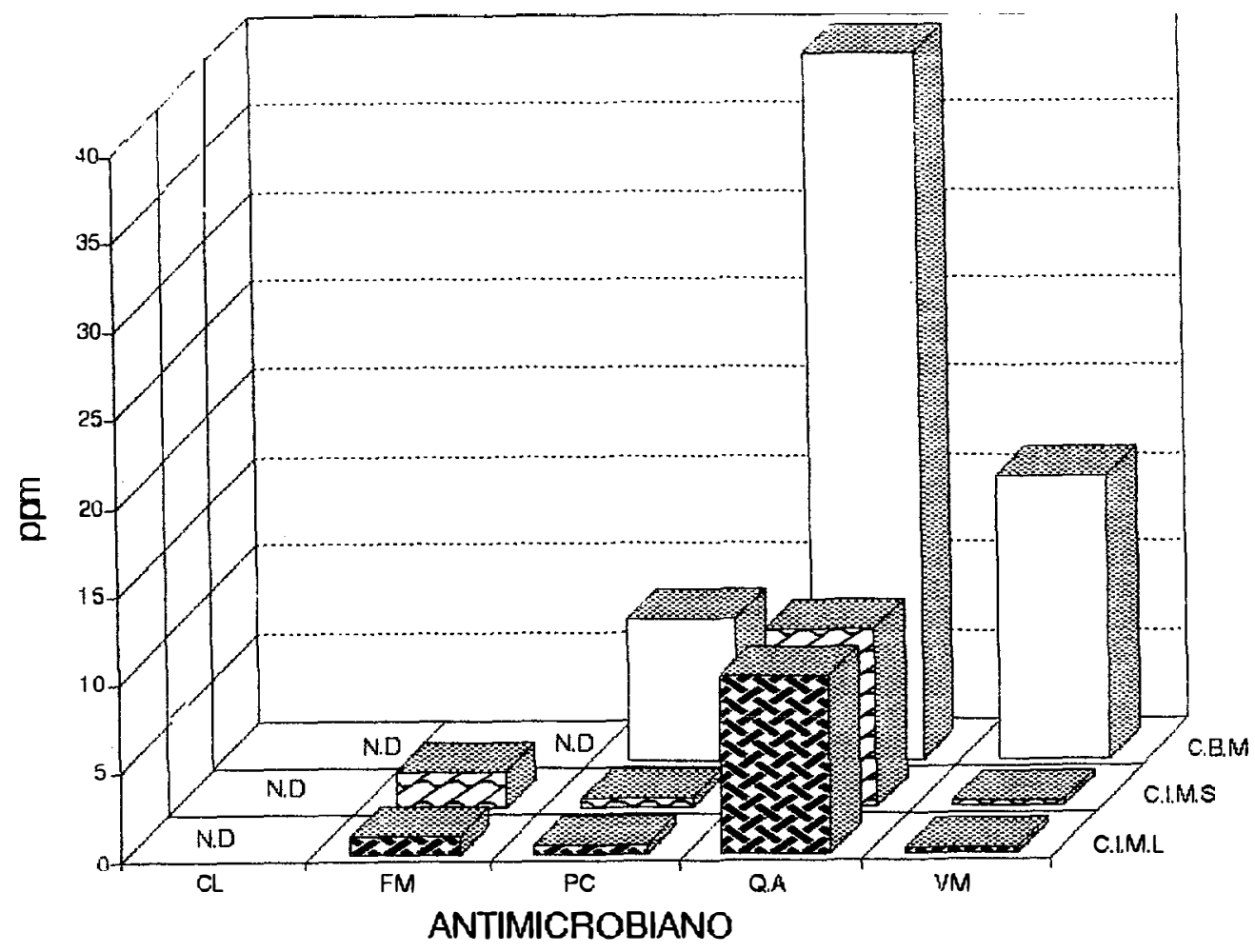

Figura 12 - Acão dos antimicrobianos testados sobre $B$. brevis quanto à: C.I.M.L, C.I.M.S e C.B.M onde CL - cloranfenicol, FM - fermacol, PC - penicilina, Q.A - quaternário de amônio, VM - virginiamicina e ND - não detectado. 


\subsubsection{Bacillus megaterium}

A Figura 13 e a Tabela 2 mostram a ação de todos os antimicrobianos para $B$. megaterium.

Para que esta bactéria fosse inibida foram necessários: $4 \mathrm{ppm}$ de cloranfenicol, $0.25 \mathrm{ppm}$ de fermacol, $0.5 \mathrm{ppm}$ de penicilina, $10 \mathrm{ppm}$ de quaternário de amônio e 0.25 ppm de virginiamicina. Para a C.B.M são necessários 4 ppm de fermacol, 20 ppm de quaternário de amônio e 2 ppm de virginiamicina. Para os antimicrobianos cloranfenicol e penicilina esta dose letal não foi obtida com as maiores concentrações utilizadas (16 ppm).

RODINI (1989), trabalhou com esta bactéria e cita que esta, ainda tem a capacidade de crescer quando colocada em doses de até 400 ppm de penicilina.

Segundo PRINCIPAIS bactérias contaminantes da fermentação alcoólica, suas características e sensibilidade a antibióticos (1991), essa bactéria quando colocada em contato com virginiamicina e penicilina em uma concentração de 1 ppm por três horas é reduzida ao nível de 41.2 e 8 용 respectivamente e frente ao fermacol, nas mesmas condições, não houve redução. Para tempo de contato de seis horas as reduções foram de $64.7 \%$ para virginiamicina, $44 \%$ para penicilina e não houve redução para o fermacol. 


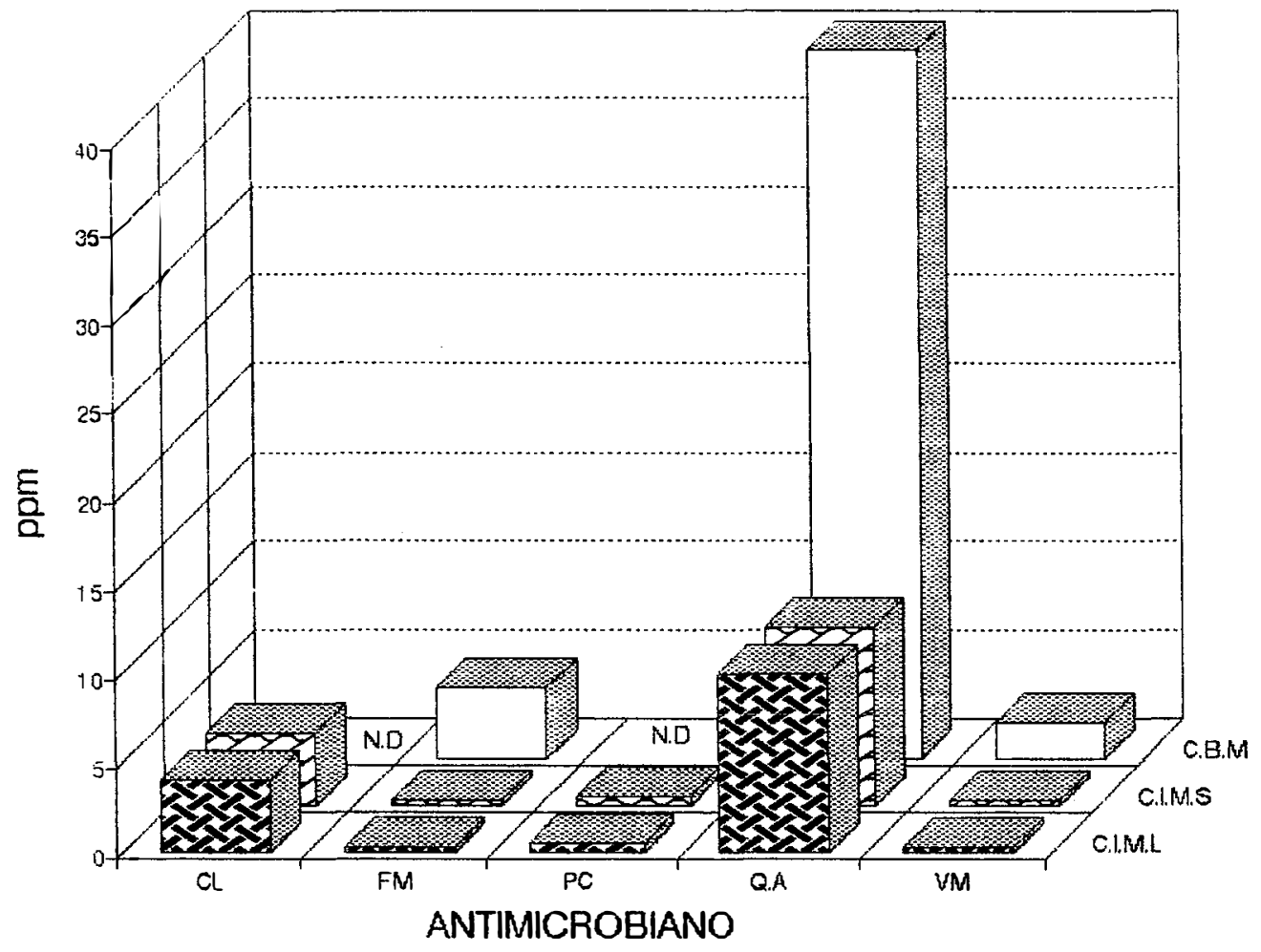

Figura 13 - Acão dos antimicrobianos testados sobre $B$. megaterium quanto à: C.I.M.L, C.I.M.S e C.B.M onde CL cloranfenicol, FM - fermacol, PC - penicilina, Q.A quaternário de amônio, VM - virginiamicina e ND - não detectado. 


\subsubsection{Bacillus coagulans}

A Figura 14 e a Tabela 2 mostram a ação de todos os antimicrobianos sobre B. coagulans.

Para a inibição deste microrganismo foram necessários: $4 \mathrm{ppm}$ de cloranfenicol, $0.25 \mathrm{ppm}$ de fermacol, 10 ppm de quaternário de amônio e 0.5 ppm de virginiamicina. Quanto a penicilina, este produto não foi eficiente em dosagem igual a $16 \mathrm{ppm}$ para inibir este microrganismo. No caso da C.B.M esta, foi conseguida com doses de 4, 40 e 2 ppm respectivamente para fermacol, quaternário de amônio e virginiamicina. Para os outros dois produtos, (cloranfenicol e penicilina) 16 ppm destes produtos não foram letais para este microrganismo.

Segundo PRINCIPAIS bactérias contaminantes da fermentação alcoólica, suas características e sensibilidade a antibioticos (1991), essa bactéria quando colocada em contato com virginiamicina em uma concentração de 1 ppm por três horas é reduzida ao nível de $48.4 \%$ e para penicilina e fermacol nas mesmas condiçōes, reduçōes significativas não foram observadas. As mesmas tendências foram observadas para tempo de contato de 6 horas, sendo que o índice de redução para virginiamicina aumentou para $65.7 \%$. 


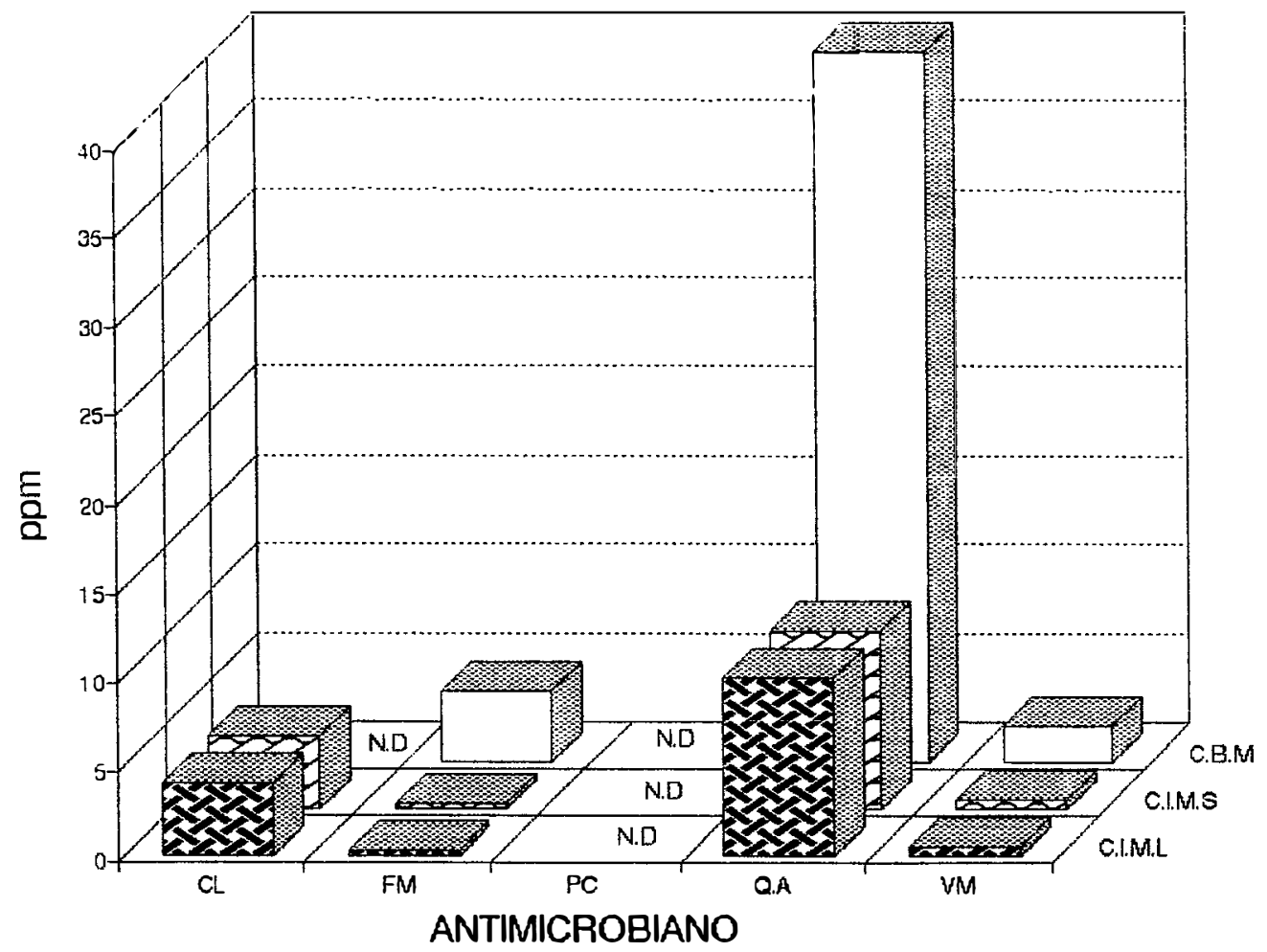

Figura 14 - Acão dos antimicrobianos testados sobre $B$. coagulans quanto à: C.I.M.L, C.I.M.S e C.B.M onde CL cloranfenicol, FM - fermacol, PC - penicilina, Q.A quaternário de amônio, VM - virginiamicina e ND - não detectado. 


\subsubsection{Bacillus subtilis}

A Figura 15 e a Tabela 2 mostram a ação de todos os antimicrobianos sobre $B$. subtilis.

Para inibição deste microrganismo foram necessários: 2-4 ppm de cloranfenicol, 0,25 ppm de fermacol, 2 ppm de penicilina, 10 ppm de quaternário de amônio e 0.5-1 ppm de virginiamicina. No que diz respeito a C.B.M são necessário 2, 40 e 2 ppm de fermacol, quaternário de amônio e virginiamıcina respectivamente. Já para cloranfenicol e penicilina a C.B.M não foi obtida em concentraçōes de até 16 ppm.

BOONSONG \& WIWUT (1985), acreditam que com doses de 10 a 20 ppm de quaternário de amônio esta bactéria pode ser controlada. OLIVEIRA et al. (1987), recomendam como eficiente, doses de 50 e 100 ppm de quarternârio de amônio quando este produto tem porcentagem de 48.9 e 50.75 de matéria ativa, respectivamente, para 0 controle de $B$. subtilis. ROSALES (1989), afirma que esta bactéria quando em contato por 180 minutos com um produto a base de quaternário de amônio na dosagem de $30 \mathrm{ppm}$ é afetada sendo a redução na ordem de 44.3\%, já quando em contato pelo mesmo tempo e dosagem para o antibiótico penicilina esta redução aumenta para 60.5ㅇ․ Já RODINI (1989), testou concentraçōes de até 400 ppm de penicilina sobre $B$. subtilis, sem contudo conseguir a inibição desta bactéria.

Segundo PRINCIPAIS bactérias contaminantes da 
fermentação alcoólica, suas características e sensibilidade a antibióticos (1991), essa bactéria quando colocada em contato com virginiamicina, penicilina e fermacol por três e seis horas a uma concentração de 1 ppm não sofreu redução com nenhum dos três produtos utilizados. 


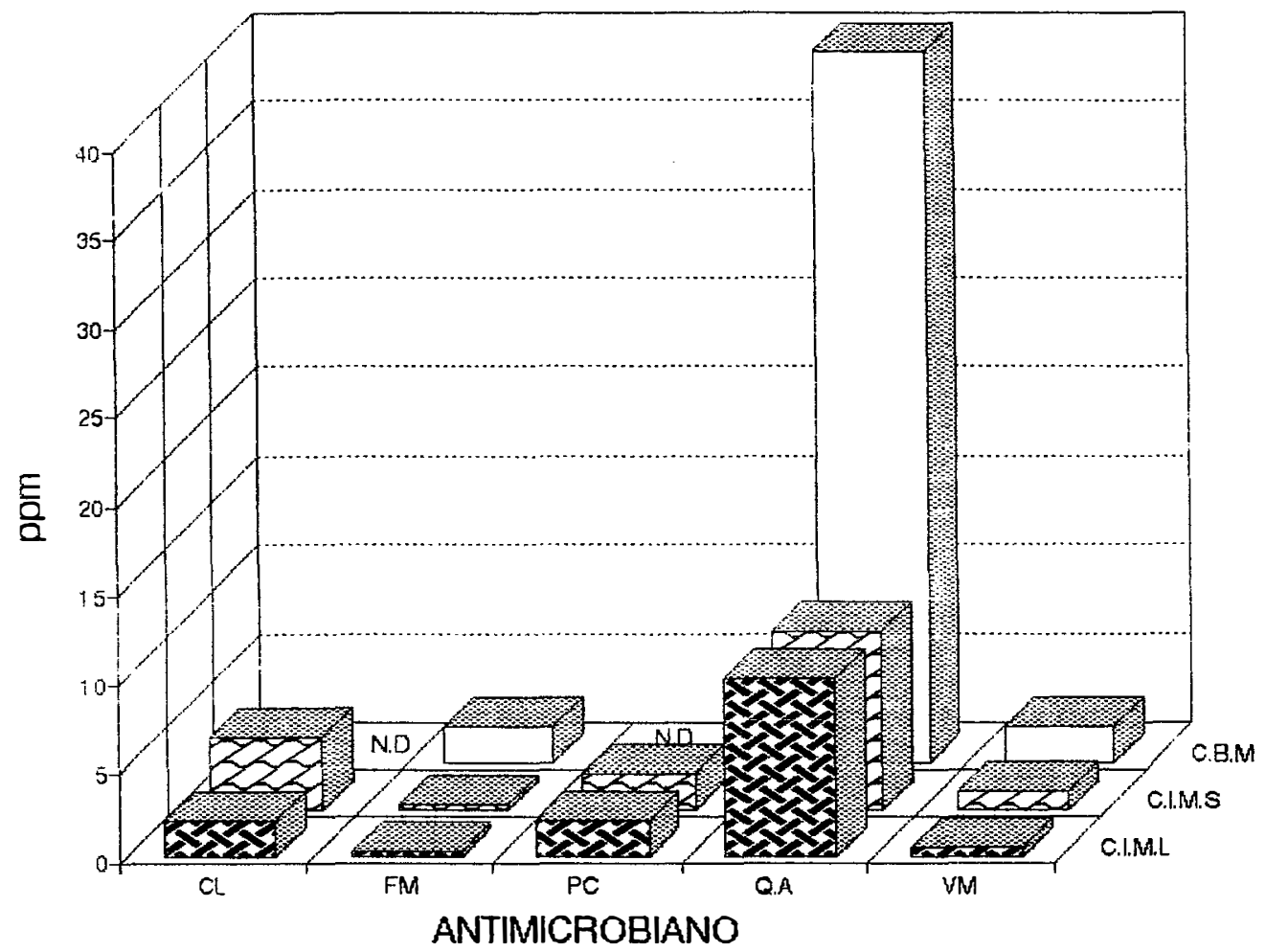

Figura 15 - Acão dos antimicrobianos testados sobre $B$. subtilis quanto à: C.I.M.L, C.I.M.S e C.B.M onde CL cloranfenicol, FM - fermacol, PC - penicilina, Q.A quaternário de amônio, VM - virginiamicina e ND - não detectado. 


\subsection{ESCOLHA DO MICRORGANISMO TESTE}

Tendo em vista a importância de todas as bactérias testadas como contaminante de fermentação adotou-se como critério para a escolha do microrganismo teste, aquele que apresentou maior resistência para todos os produtos testados, uma vez que a utilização de um determinado produto será viável em dada dose, se este for eficiente para o controle da bactéria mais resistente que esteja presente no meio. Tendo sido este critério adotado escolheu-se como bactéria teste L. plantarum, uma vez que esta foi a mais resistente para os produtos testados.

CEREDA et al. (1981), utilizaram como

microrganismo teste Leuconostoc mesenteroides, entretanto KAJI (1989), cita que este microrganismo não tem atividade quando cultivado em caldo de cana suplementado com concentrações superiores a $6 \%$ de álcool e que a velocidade especifica máxima de crescimento deste microrganismo é reduzida em mais de $50 \%$ em condições de laboratório. Esses dois fatores que limitam o crescimento desta bactéria em laboratório são constantamente encontradas nas unidades industriais.

Um outro fator que se deve levar em consideração é que segundo SILVA \& CANHOS (1989), "Leuconostoc mesenteroides muitas vezes pode ser confundido com Lactobacillus confusus, microrganismo que tem forma de cocobacilo e produz grande quantidade de goma a partir de 
sacarose (SHARPER et al., 1972).

Quando se fala em microrganismo teste, ainda se pode pensar em se utilizar $L$. fermentum, em unidades industriais que apresentam problemas de floculação, uma vez que embora seja este mais sensivel aos antimicrobianos testados está comumente associado a este fenômeno (YOKOYA, $1989 ;$ OLIVA-NETO \& YOKOYA, 1991 ).

Outros trabalhos devem ser feitos no sentido da testar outras bactérias de grande frequência como contaminantes da fermentacão alcoólica e de grande resistência à antimicrobianos, como por exemplo L. yamanashiensis, $L$. vaccinostercus, $L$. coryrifformis, $L$. helveticus e Pediococcus acidilactici. Seria interessante que cada unidade industrial, em função da origem e variedade da matéria-prima, condições climáticas e tipo de processo escolhesse a bactéria teste mais adequada a realidade da unidade. 


\section{CONCLUSÕES}

- A metodologia para determinação de C.I.M (Concentração Inibitória Mínima) em meio sólido (C.I.M.S) apresentou vantagens em relação a em meio líquido (C.I.M.L), sendo a mais importante a de se poder testar até doze (12) microrganismos em uma mesma placa de meio de cultivo.

- A determinação da C.B.M (Concentração Bactericida Mínima) parece não ser uma prática viável no setor sucralcooleiro, uma vez que esta foi obtida em apenas dezesseis (18) das quarenta (40) combinações estudadas (microrganismo/antimicrobiano), sendo que para isto foram necessárias doses muitos maiores que as rotineiramente usadas nas unidades industriais. Entretanto, esta determinação tem grande importância quando da aplicação de um dado produto como tratamento de choque.

- Os valores de C.I.M obtidos para quaternário de amônio, ao contrário do que ocorreu com os outros antimicrobianos, não variou de um microrganismo para outro (10ppm), tornando-o assim recomendável para utilização em processos industriais de fermentação alcoólica. 
- Lactobacillus plantarum foi o microrganısmo mais resistente a todos os produtos testados neste trabalho, sugerindo assim que este seja adotado como microrganismo teste.

- Os valores obtidos, tanto para C.I.M como para C.B.M devem ser avaliados levando em conta que for am obtidos em condições ideais para os microrganismos e para os antimicrobianos, pois, ambos não sofreram as ações adversas do meio de fermentação industrial (baixo pH, acidez elevada, sólido em suspensão, ação do álcool, etc) 


\section{REFERÊNCIAS BIBLIOGRÁFICAS}

ACOSTA, S. \& LODOS, J. The action of gamma radiation on sugar cane as a new sterilization method. Sugar y Azucar, 77(9): $55-9,1982$.

ALLEN, J.R. Minimizing sugar losses in harvesting and transporting cane. Australian Sugar J., 59(1): 25-9, 1967.

ALMEIDA, J.R. Álcool e distilaria. Piracicaba, Nathanael dos Santos, mimiogr., 1940. 333p.

ALTERTHUM, F.; CRUZ, M.R.M.; VAIRO, M.L.R.; GAMBASSI, D.M. Efeito dos microrganismos contaminantes da fermentação alcoólica nas microdistilarias. STAB. Açúcar, Álcoole Subprodutos, Piracicaba, 3(1): 42-9, 1984.

AMORIM, H.V.; OLIVEIRA, A.J.; CAMPOS,.H. Infecção, problema sério na produção de álcool. In: CONGRESSO NACIONAL DA SOCIEDADE DOS TECNICOS AÇUCAREIROS DO BRASIL, 2. , 1981. Anais. p.158-68. 
AMORIM, H.V. \& OLIVEIRA, A.J. Infeç̧ão na fermentação: como evitá-la. Alcool e Açúcar, 5: 12-8, 1982.

AQUARONE, E. Influência de antibióticos na fermentação alcoólica de mosto de melaço de cana. S. Paulo, 1959. 139p. (Livre-docência - Faculdade de Farmácia e Odontologia da Universidade de S. Paulo.)

AQUARONE, E. Contribuição ao estudo do emprego de associações de antibióticos como desinfetantes em fermentações alcoólica. S.Paulo, 1968. 120p. (Catedra - Faculdade de Farmácia e Bioquímica da Universidade de S.Paulo.)

AQUARONE, E.; BARUFFALDI, R.; PASSOS, J.B.P. Dados sobre o emprego de penicilina na produção de álcool em escala industrial no nordeste. Rev. Fac. Bioguim. Univ. S. Paulo, $4(1): 103-18,1966$

AYALA, H.G.; LIMPIAS,D.B.; DELFINI, A.; GARGIULO, C.A. Action of some bactericides on raw sugarcane juice. In: I.S.S.C.T.,16., São Paulo, Brazil, Proceedings, 1977. p. 2909-23.

BERKWITH, T.D. The bacteriology of pulp slime. $\underline{\mathrm{J} .}$ of Bacteriology, 22: 15-22, 1931. 
BERTELLI, L.G. Dezesseis anos de Proálcool. STAB, Acúcar,_Álcool e Subprodutos. 11(1): 19-20, 1992.

BEVAN, D. \& BOND, J. Microrganism in field and mill - A preliminary survey. In: CONFERENCE OF SOC. SUGAR CANE TECHNOL., 38., Proceedings, 1971. p.137-43.

BOONSONG, S. \& WIWUT, D. Quartenary ammonium compounds, Chemical control of bacteria in sugar cane by using quartenary ammonium compounds. Kasetsart J., 19(3): 21320, 1985. Apud Tate \& Lyle's SIA, 49(3): 97, 1987. (Resumo) .

BOVI, M.P. \& MARQUES, G.E. O tratamento ácido na fermentação alcoólica. Álcool e Acúcar. 3(9): 10-13, 1982.

BRASS, C.; SHAINHOUSE, J.Z.; STEVENS, D. Variability of agar dilution replicator of susceptibility testing. Antimicrobial Agents and Chemotherapy, 15(6): 763-68, 1979 .

BRAUNBECK, M.D.W. Efeito de biocidas sobre o comportamento de leveduras e o rendimento da fermentação. Piracicaba, 1988. 156p. (Mestrado - Escola Superior de Agricultura "Luiz de Queiroz" /USP ) 
BRUIJN, J. Deterioration of sugar cane after harvesting part I. Investigation of the polysaccharide formed. Int. Sugar J., 68: 356-58, 1966a.

BRUIJN, J. Deterioration of sugar cane after harvesting part II. Changes in juice composition. Int. Sugar J., 68: 33$34,1966 \mathrm{~b}$.

CAMHI, J.D. A fermentação alcoólica e sua otimização. Brasil Acucareiro, 94(2): 126-32, 1979.

CEREDA， M.P.; SERRA， G.E.; CAGLIARI， M.A.; MENEguiM, M.A. Métodos microbianos de avalição de antissépticos empregados em indústrias alcooleiras. Brasil Acucareiro, $3: 44-50,1981$.

CLARK, M.A.; ROBERTS, E.J.; GODSHALL, M.A.; BRANNAN, M.A. CARPENTER, F.G.; COLL, E.E. Sucrose loss in manufacture of cane sugar. Sugar y Azucar, 75(9): 64-8, 1980.

CONTROLE microbiológico na fabricação de açúcar e álcool. Boletim Técnico Copersucar, São Paulo, 22: 3-17, 1983. 
COSTA, M.F.; ANGElis, D.F.; LAFRAtA, E.A.; BRUNElli, W.F. Proposta de uma rotina rápida para avaliação da perda de sacarose mediante aplicação de biocida em caldo primário. In: CONGRESSO NACIONAL DA STAB e CONVENÇÃO DA ACTALAC, 4. e 7., Olinda, 1987. Anais. p. 531-34.

CRUZ, M.R.M.; VAIRO, M.L.R.; GAMPASSI, D.M. Influência da penicilina V-ácida no controle de infecções bacterianas na fermentação alcoólica. Revista de Microbiologia S.B.M. $16(2): 138-42,1985$.

DUCAN, C.L. \& COLMER, A.R. Coliforms associated with sugar cane plants and juices. Applied Microbiology, 12(2): 173177,1964 .

EGAN, B.T. The infection process in sour storage rot. In: CONFERENCE OF THE QUEENSLAND SOCIETY OF SUGAR CANE TECHNOLOGISTS, 32., 1965. Proceedings. p.21-4.

EGAN, B.T. How long can chopper cane be stored?. Sugar J., $34(4): 21,1971$.

EGUCHI, S.Y. Agentes Antimicrobianos. In: EGUCHI, S.Y.; YOKOYA, F.; CANHOS, V.F.; GALLO, C.R. POntos Críticos Microbiólogicos em Usinas de Acúcar e Álcool. Campinas, Fundação Tropical de Pesquisas "Ándre Tosello", 1989. p.1- 
22 .

FERRARI, S.E. \& RODELLA, A.A. Ocorrência de dextrana em cana de açúcar. Brasil Açucareiro, XV(5): 19-22, 1977.

FOSTER, D.H. Sugar processing difficulties. Sugar J., 60: $529-31,1969$.

FRANCO, C.J. Fermentação alcoolica. Saccharum, 3: 31-6, 1978.

FURLETTI, M.E.M.; OLIVEIRA， M.C.F.L.; ANGELIS, D.F. Perspectiva de uso de biocidas não convencionais na desinfecção da fermentação etanólica. Brasil Acucareiro, $48(3): 220-23,1981$.

GALLI, Z.F. Fermentação do mel final das usinas de açúcar. In: SEMANA DE FERMENTAÇÃO ALCOÓLICA, 2. , Piracicaba, 1961. 2 : $297-304$.

GALLO, C.R. Determinação da microbiota bacteriana de mosto e de dornas de fermentação alcoólica. Campinas. 1989, 388p. (Doutorado - Faculdade de Engenharia de Alimentos/UNICAMP). 
GAYLARDE, C. \& LATORRE, W.C. Problemas de biodeterioração na indústria brasileira de açúcar e álcool. Biodeterioration Abstracts, $4(3): 219-25,1990$.

GENTRY, J.P. \& GASCHO, G.J. Deterioration of sugar cane as affected by lenght of cut and delay in milling. Amer. Soc. Agric. Eng., 105: 1-5, 1972 .

GUILLILAND, R.B. \& LACEY, J.P. Lethal action by Acetobacter on yeast. Nature, London, 202: 727-28, 1963. Apud J. Inst. Brew., 70: 537, 1964. (Resumo)

GUTIERREZ, L.E.; AMORIM, H.V.; BASSO, L.C. Inibidores da fermentação alcoólica. STAB. Acúcar, Álcool e Subprodutos, Piracicaba, 9(6): 24-9, 1991 .

HES, J.W. The deterioration of harvest cane. Int. Sugar J., $4: 102-4,1952$.

JOLLY, S.L. \& PRAKASH, Removal of dextran from cane juice. Int. Sugar J., 89: 184-86, 1987.

KAJI, D.A. Influência da temperatura e infecção lática na fermentação alcoólica. Campinas. 1989, 136p. (Mestrado Faculdade de Engenharia de Alimentos/UNICAMP). 
KAJI, D.A. \& CANHOS, V.P. Contaminantes de processos de produção de açúcar e álcool. In: EGUCHI, S.Y.; YOKOYA, F.; CANHOS, V.F.; GALLO, C.R. Pontos Críticos Microbiólogicos em Usinas de Açúcar e Álcool. Campinas, Fundação Tropical de Pesquisas "Andre Tosello", 1989. p.1-9.

KENERY, J.S.; LEE, J.B.; DAVIS, C.W. Deterioration of mechanically harvested chopped-up cane. Part I - Dextran A promising quantitative indicator of the processing quality of chopped-up cane. I. sugar J., 69: 330-33, 1967.

KENNY, M.T.; DULWORTH, J.K.; BRACKMAN, M.A. Comparison of the agar dilution, tube dilution and broth microdilution susceptibility tests for determination of teicoplanin MICs. Journal of Clinical Microbiology, 27(6): 1409-10, 1989 .

KHAN, A.R. \& HOQ, M.M. Lactic acid bacteria as contaminants in alcohol fermentation. Bangladesh J. of Microbiology, 7(2): 119-21, 1990. Apud Sugar Industry Abstrat, 54(2): 55,1992 . (Resumo)

LAWRENCE, C.A. \& BLOCK, S.S. Densinfection, Sterilization and Preservation, Philadelphia, Lea \& Febiger, 1968.808p. 
LIMA, U.A.; GOLDONI, J.S.; CEREDA, M.P.; SOUZA, L.G. Ocorrência de microrganismo em caldo bruto, caldo misto e água de embebição em usinas de açúcar de cana. Brasil. Acucareiro. $12(4): 337-43,1974$.

LOBO, M.R.O.; SOUZA, R.G.; TOLEDO, A.C.; DUTRA, A.D. Avaliação do desempenho de diversos sistemas de água de lavagem de cana em Alagoas. STAB. Açúcar, Álcoole Subprodutos, Piracicaba, 5(5/6): 39-53, 1987.

LOPEZ, Z.O.; MORENO, I.E.; FOGLIATA, F.A.; AYALA, H.G. Microbial population of sugar juice thas is neither affected nor deteriorated by frost. Sugar y Azucar, 83(9): $21-33,1988$

LUCREDI， H.A.; FINGUERUT, J.; ROSSELL, C.E.V.; YOKOYA，F. Verificação da esterilidade do sistema de tratamento térmico do caldo de cana-de-açúcar para a fermentação. Boletim Técnico Copersucar, 27(84): 25-8, 1984.

MacMASTER, L.D. \& RAVNO; A.B. Sucrose loss in difusion with reference to thermophilic bacteria and lactic acid. In: SOUTH AFRICAN SUG. TECH. ASSIS., 1975. Proceedings 49: 4952 . 
MacMASTER, L.D. \& RAVNO, A.B. The ocorrence of lactic acid and associated micro-organism in cane sugar. In: CONGRESS I.S.S.C.T., 16., São Paulo, 1977. Proceeding. p.1-14.

MAIORELLA, B.; BLANCH, H.W.; WILKE, C.H. By product inibition effects on ethanolic fermentation by Saccharomyces cerevisiae. Biotecnol. and Bioeng., 25: 103-21, 1983.

MASSON, N.P.M.; BALBO, A.N. Tratamento de água das torres de resfriamento. STAB, Açúcar, Álcool e Subprodutos, 10(1): $42-6,1991$

MAYEUX, P.A. \& COLMER, A.C. studies on microflora associated with Saccharum officinarum. The Sugar J., 23(7): 28-32, 1960.

NEVES, L.B. Tecnologia da fabricação do álcool. Rev. Bras. Química, 3: 89-134, 1938 .

OLIVA-NETO, P. Influência da contaminação por bactérias láticas na fermentação alcoólica pelo processo bateladaalimentada Campinas. 1990, 199p. ( Mestrado - Faculdade de Engenharia de Alimentos/UNICAMP) 
OLIVEIRA, M.C.F.L.; ANTUNES, G.M.S.; SACRAMENTO, S. Estudo prévio para normatização de técnicas para avaliação de bactericidas. In: CONGRESSO NACIONAL DA STAB E CONVENÇÃO DA ACTALAC, 4. e 7., Olinda, 1987. Anais. p.547-61.

OLIVEIRA， M.C.F.L.; FURLETti, M.E.M.; ANGELIS, D.F. Novos biocidas propostos à indústria alcooleira. (I) Análise do desempenho do Busan 881. In: SIMPÓSIO NACIONAL DE FERMENTAÇÃo, 5., Viçosa, 1982. Anais.

ONNA, K.M. \& HASHIMOTO, W.K. Economics of using a biocide at milling tandem. Int. Sugar J., 91(1092): 232-34, 1989.

PEDERSON, C.S. \& HUCKER, G.J. The significance of bacteria in sugar mill.s. In: MEETG. ASSOC. DE TECH. AZUCAREROS DE CUBA, 20., Cuba, 1946. Anais. p. 225-230.

PILON, J.R. \& BERTOLINI, M.C. Avaliação da flora bacteriana em uma indústria sucro-alcooleira durante uma safra. In: CONGRESSO BRASILEIRO DE MICROBIOLOGIA. 15., Ribeirão Preto, 1989. Resumos. São Paulo, Sociedade Brasileira de Microbiologia, 1989. p.176.

PRINCIPAIS bactérias contaminantes da fermentação alcoólica, suas caracteristicas e sensibilidade a antibióticos. Piracicaba, Fermentec s/c Ltả., 1991. 41p. 
RAVELO, S.B.; RAMOS, E.L.S.; TORRES, B.M.T.P. Inhibition of oligo and polysaccharide formation during sugar cane deterioration. Int. Sugar J., 93(1113): 180-200, 1991.

RHIGHI, J.C.I. Técnicas utilizadas no corte da cana de açúcar. In: SEMINÁRIO DA AGROINDUSTRIA AÇUCAREIRA, 3., Águas de Lindóia, 1975. Anaıs. p. 367-379.

ROCHA, H.; ZULIANI, M.E.; TRABULSF, L.R. Antibiograma. Revista de Microbiologla, 3(1): 51-60, 1972.

RODINI, M.A.T. Isolamento, caracterização e identificação de bactérias contaminantes de dornas de fermentação nas destilarias de etanol. Piracicaba, 1985, 92p. (Mestrado Escola Superior de Agricultura "Luiz de Queiroz"/USP)

RODINI, M.A.T. Bactérias contaminantes do processo de fermentação de etanol e sua sensibilidade frente à penicilina e pentaclorofenol. STAB, Açúcar, Álcoole Subprodutos, Piracicaba, 8(2): 52-4, 1989.

ROSALES, S.Y.R. Contaminantes bacterianos da fermentação etanólica: isolamento em meios diferenciais, identificação e avaliação de desinfetantes. Rio Claro, 1989. 200p. (Doutorado - Universidade Júlio de Mesquita Filho/UNESP) 
ROSALES, S.Y.R.; ANGELIS, D.F.; FURLETTI, M.E. The effect of four genera of bacteria upon the saccharomyces carlbergensis (Iz 1904) in the floculation and reproduction. In: CONGRESSO DO ISSCT, 20., S.Paulo, 1989.

SATTO, S.; BRAZZACH, L.B.; AQUARONE, E. Estudo comparativo entre vários desinfetantes para controle de contaminação nas fermentações alcoólicas de mostos de melaço de cana. Rev. Farm. Bioquim. Univ. S. Paulo, 16:(1/2): 122-32, 1980.

SEKI， M.; KANEUCHI， C.; KUMNNANTA， J .; MANTIRUNGIJ, M.; OHMONO, T.; KOMAGATA, K. Identification of lactic acid bacteria isolated from fermented cane molasses at alcohol plants in Thailand, Bulletin of the Japan Federation for culture collection, 5(2): 80-8, 1989. Apud Sugar Industry Abstracts, 52(4): 115, 1990. (Resumo)

SERRA， G.E.; CEREDA， M.P.; FERES， R.J.; BERTOZO， M.T.; VICENTE, A.T. Contaminação da fermentação alcoólica " floculação do fermento" Brasil Acucareiro, 93(6): 26-31, 1979 .

SERRA， G.E.; CEREDA， M.P.; MENEGUIN, M.A.; PINTO， S.Z.; MARINO, E.A.; FERREIRA, L.J.; BETHIOL, A.E. Controle biológico da fermentação alcoólica em condições 
industriais. In: SIMPÓSIO INTERNACIONAL SOBRE TECNOLOGIA DOS ÁLCOOIS COMO COMBUStivet, 4., Guarúja, 1980.

SHARPER, M.E.; GARVIE, E.I.; TILBURY, R.H. Some slime forming heterofermentative species of the genus Lactobacillus. Applied Microbiology, 23(2): 389-97, 1972.

SHEATA, A.M.E. Yeast isolated from sugar cane and its juice during the production of aguardente de cana. Applied Microbiology, 8: 73-5, 1960 .

SILVA, N. Influência do resfriamento em torre sobre a microflora do caldo de cana no processo de produção de álcool. Campinas. 1988, 117p. ( Mestrado - Faculdade de Engenharia de Alimentos/UNICAMP)

SILVA, N. \& CANHOS, W.P. Microbiologia de Processo: Contaminação - Parte 1 - Grupo de microrganismos relevantes em usinas de açúcar e álcool. In: EGUCHI, S.Y.; YOKOYA, F.; CANHOS, V.F.; GALLO, C.R. Pontos Críticos Microbiologicos em Usinas de Acúcar e Álcool. Campinas, Fundação Tropical de Pesquisas "André Tosello", 1989. p. $1-22$. In: 
SKOLE, R.D.; HOGU, J.N.; RIZATTO, A.B. Microbiology of sugar: a taxonomie study. In: TECH. SESS. CANE SUGAR REFINING. Res., New Orleans, 1977.

SMITHLKLINE. Virginiamicina. s.l., s.d. 95p. (Manual Técnico)

SOUZA, L.G.; GOLDINI, J.S.; EIRA, A.F. Microrganismo em melaço armazenado. Brasil Açucareiro, 4: 204-6, 1977.

STEERS, E.; FOLTZ, E.L.; GRAVES, B. An inocula replicating apparatus for routine testing of bacterial suseeptibility to antibiotics. Antibiotics and Chemotherapy, 4(5): 307$311,1959$.

STUPIELLO, J.P. Qualidade da cana-de-açúcar para fabricação de açúcar e álcool. Acúcar e Álcool, 2: 28-32, 1982.

STURION, A.C.; FERREIRA, L.J.; ROSSETO, A.J. Deteriração de toletes de cana-de-açúcar. In: SEMINARIO COPERSUCAR DA AGROINDÚSTRIA AÇÚCAREIRA, 3. , Água de Lindóia, 1975. Anais. p. 381-87.

SUTHERLAND, D.N. \& PATON, N. Dextran and crystal elongation: further experiments. Int. Sugar J., 71: 131-35, 1969. 
TANTAOI, M. Dextran its effects on polarization and true sucrose determination in sugar juice. Sugar J., 15(6): 368,1952

TILBURY, R.H. Biodeterioration of harvest sugar cane. In: WALTERS, A.H. \& ELPHICK, J.J. Biodeterioration of materials. Amsterdan, Elsevier, 1968. p.717-30.

TILBURY, R.H. Dextrans and dextranase. In: I.S.S.C.T., 14., 1971. Proceeding. p. 1444-59.

TILBURY, R.H. Occurrence and effects of lactic acid bacteria in sugar industry. In: CAN, J.G.; CUTING, C.V.; WHITING, G.C. Lactic acid bacteria bacteria in beverages and foods. London, Academic Press, 1975. p.177-91.

TILBURY, R.H.; HOLLINGSWORTH， B.S.; GRAHAM, S.D.; POTTAGE, P. Mill sanitation - A fresch approch to biocide evaluation. In: I.S.S.C.T., 16., São Paulo, 1977. Proceedings. 3: $2749-68$.

VAN ZELLER, A.L.; OLIVEIRA, A.J.; ZAGO, E.A. Conservação de xarope de cana-de-açúcar pelo emprego da radiação gama. STAB, Acúcar, Álcool e Subprodutos. 2(4): 29-36, 1984. 
VAUGHAN, R.B. Leveduras e fermentação alcoólica. São Paulo, Ed. da "Chacara e Quintaes", 1934. 61p.

YOKOYA, F. Microbiologia de Processo. In: EGUCHI, S.Y.; YOKOYA, F.; CANHOS, V.F.; GALLO, C.R. Pontos Críticos Microbiologicos em Usinas de Acúcar e Álcool. Campinas, Fundação Tropical de Pesquisas "André Tosello", 1989. p. $1-22$.

YOKOYA, F. \& OLIVA-NETO, P. Caracterização da floculação de leveduras por Lactobacillus fermentum. Rev. Microbiol. $22(1): 12-16,1991$.

ZARPELON, F. \& ANDRIETTA, S.R. Fermentação contínua para produção de álcool. STAB, Acúcar, Álcool e subprodutos. $10(4): 23-28,1992$. 